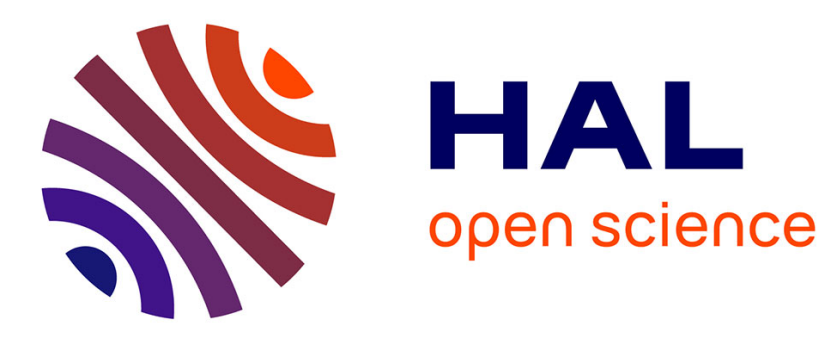

\title{
Lago Mare and the Messinian Salinity Crisis: Evidence from the Alboran Sea (S. Spain)
}

Damien Do Couto, Speranta-Maria Popescu, Jean-Pierre Suc, Mihaela Carmen Melinte-Dobrinescu, Nadia Barhoun, Christian Gorini, Laurent Jolivet, Jeffrey Poort, Gwenael Jouannic, Jean-Luc Auxietre

\section{To cite this version:}

Damien Do Couto, Speranta-Maria Popescu, Jean-Pierre Suc, Mihaela Carmen Melinte-Dobrinescu, Nadia Barhoun, et al.. Lago Mare and the Messinian Salinity Crisis: Evidence from the Alboran Sea (S. Spain). Marine and Petroleum Geology, 2014, 52, pp.57-76. 10.1016/j.marpetgeo.2014.01.018 . insu-00949133

\section{HAL Id: insu-00949133 \\ https://hal-insu.archives-ouvertes.fr/insu-00949133}

Submitted on 20 Feb 2014

HAL is a multi-disciplinary open access archive for the deposit and dissemination of scientific research documents, whether they are published or not. The documents may come from teaching and research institutions in France or abroad, or from public or private research centers.
L'archive ouverte pluridisciplinaire HAL, est destinée au dépôt et à la diffusion de documents scientifiques de niveau recherche, publiés ou non, émanant des établissements d'enseignement et de recherche français ou étrangers, des laboratoires publics ou privés. 


\section{Lago Mare and the Messinian Salinity Crisis: Evidence from the Alboran Sea (S. Spain)}

\section{Damien Do Couto ${ }^{1-2}$, Speranta-Maria Popescu ${ }^{3}$, Jean-Pierre Suc ${ }^{1}$, Mihaela Carmen Melinte-Dobrinescu ${ }^{4}$, Nadia Barhoun ${ }^{5}$, Christian Gorini ${ }^{1}$, Laurent Jolivet ${ }^{6}$, Jeffrey Poort $^{1}$, Gwénaël Jouannic ${ }^{7}$, Jean-Luc Auxietre ${ }^{2}$}

1, Université P. \& M. Curie, ISTEP, UMR 7193, 75005 Paris, France

CNRS, ISTEP, UMR 7193, 75005 Paris, France

(docoutodamien@gmail.com, jeanpierre.suc@gmail.com, christian.gorini@gmail.com)

2, TOTAL, 2 place Jean Millier, 92400 La Défense, Paris, France (jeanluc.auxietre@total.com)

3, GeoBioStratData.Consulting, 385 route du Mas Rillier, 69140 Rillieux la Pape, France (speranta.popescu@gmail.com)

4. National Institute of Marine Geology and Geoecology, 23-25 Dimitrie Onciul street, P.O. Box 34-51, 70318 Bucharest, Romania (melinte@geoecomar.ro)

5. University Hassan II-Mohammedia, Faculty of Sciences Ben M'Sik, BP 7955 Sidi Othmane, Casablanca, Morocco (nbarhoun@yahoo.fr)

6, Université d'Orléans, ISTO, UMR 7327, 45071 Orléans, France

CNRS/INSU, ISTO, UMR 7327, 45071 Orléans, France

BRGM, ISTO, UMR 7327, BP 36009, 45060 Orléans, France

(laurent.jolivet@univ-orleans.fr)

7, Cerema, DTer Est, Laboratoire Régional des Ponts et Chaussées de Nancy, 54510 Tomblaine, France (gwenael.jouannic@cerema.fr)

\section{Corresponding author}

Damien Do Couto, ISTEP, Université P. \& M. Curie, Case 129, 4 place Jussieu, 75252 Paris Cedex 05, France (e-mail address: docoutodamien@gmail.com) 


\begin{abstract}
This paper provides a new environmental, sedimentological and stratigraphic context of the Lago Mare deposits from the North Alboran region and clarifies their chronologic location with respect to the Messinian Salinity Crisis. We present new micropaleontological data (dinoflagellate cysts, calcareous nannoplankton, planktonic foraminifers), correlated with field observations and offshore seismic interpretations. We show that the Lago Mare event known in three onshore localities (Río Mendelín near Malaga, Zorreras near Sorbas, Gafares near Níjar) follows the marine reflooding of the Mediterranean Basin which ended the Messinian Salinity Crisis. Chronologically, these Lago Mare deposits last from the latest Messinian to the early Zanclean. In fact, the first influx of Paratethyan- organisms is revealed by the dinoflagellate cyst record from near Malaga within a Gilbert-type fan delta overlying the Messinian Erosional Surface. Invading molluscs and/or ostracods may have persisted in lagoonal coastal areas more or less affected by discontinuous marine influxes (Sorbas and Níjar). The Malaga area is convenient for a paleogeographic and sedimentary reconstruction which shows the prevalent forcing of sea level changes during the time-interval 5.600-5.332 Ma at the difference of the usually solicited prevalent tectonics. The studied Lago Mare event is the third episode resulting in such a paleobiological assemblage in the Mediterranean region and corresponds to the final two-way water exchange at high sea level between the Mediterranean and the former Paratethys. It documents the onset of the modern marine circulation in the Mediterranean after the reflooding ending the Messinian Salinity Crisis.
\end{abstract}


Key-words: Dinoflagellate cysts, Calcareous nannoplankton, Lago Mare, Alboran Sea, Messinian Salinity Crisis, Post-crisis reflooding.

Highlights: >Dinoflagellate cysts identify the right invasion level by Paratethys waters. >Alboran Lago Mare immediately followed the post-Messinian Salinity Crisis marine reflooding. > Lago Mare must be discarded in the sense of a unique chronostratigraphic unit.

\section{Introduction}

In the Mediterranean Basin, the term Lago Mare designates a deposit related to the Messinian Salinity Crisis ${ }^{1}$ characterized by brackish water environments. Such deposits are usually considered to have preceded marine reflooding (Cita and Colombo, 1979), but recent researches suggest that they may have coexisted with it (Clauzon et al., 2005; Popescu et al., 2009). The biofacies of the Lago Mare deposit is characterized by molluscs and/or ostracods and/or dinoflagellate cysts of Paratethyan-type (i.e., of brackish affinity; Gignoux, 1950; Ruggieri, 1962; Cita and Colombo, 1979; Bertini et al., 1995; Orszag-Sperber et al., 2006).

The Lago Mare has long been considered a unique chronostratigraphic unit overlying the Messinian evaporites (Hsü et al., 1973) generated by a rapid flow of low salinity waters from the Paratethyan basins (Dacic and Euxinian, i.e. the Black Sea s.l.) into the almost completely desiccated Mediterranean Basin (Cita et al., 1978). Consequently, the identification of the Lago Mare type biofacies has often been considered useful for a late Messinian age. In the last decades, this concept has been contradicted by significant

\footnotetext{
${ }^{1}$ Messinian Salinity Crisis $=$ MSC ; Messinian Erosional Surface $=$ MES.
} 
findings. Firstly, a substantial sea level fall affected the Black Sea according to a clear erosional surface (Gillet et al., 2007) overlain by clastic material (the so-called 'pebbly breccia': Hsü, 1978). This event has been unambiguously ascribed to the time of the MSC because of the latest Messinian age at $5.45 \mathrm{Ma}$, indicated by calcareous nannofossils conjointly with climatostratigraphy, of the sediments which immediately overlie the pebbly-breccia (Popescu et al., 2010). The robust datation of this sea-level fall prevents any coeval overflow of the Black Sea into the Mediterranean Basin. Moreover, the Paratethyan basins appear to have been invaded twice by Mediterranean calcareous nannoplankton, often associated with foraminifers and dinoflagellate cysts, within the time-interval of the MSC which suggests marine incursions from the Mediterranean Sea (Mărunţeanu and Papaianopol, 1995, 1998; Clauzon et al., 2005; Snel et al., 2006; Popescu et al., 2009; Suc et al., 2011).

According to Clauzon et al. (2005) two incursions of Mediterranean marine waters entered the Eastern Paratethys during high sea level periods. Simultaneously, two inflows of Paratethyan waters entered the Mediterranean. This new concept of two-way water exchanges between the Mediterranean and Eastern Paratethys led to the chronological distinction between three Lago Mare events (Fig. 1; Clauzon et al., 2005). Lago Mare 1 (ca. $5.640-5.600 \mathrm{Ma}$; Fig. 1) overlies the peripheral evaporites and is topped by the Messinian Erosional Surface ${ }^{1}$ (Clauzon et al., 2005; Popescu et al., 2009) whereas Lago Mare 3 (ca. 5.460 - 5.332 Ma; Fig. 1) follows the reflooding of the Mediterranean Basin and has been precisely dated by calcareous nannofossils in several places (Clauzon et al., 2005; Popescu et al., 2007, 2009; Bache et al., 2012). Such episodes correlated with high sea levels are supported by the occurrence of fish living in normal marine conditions in 
Lago Mare deposits from Italy (Carnevale et al., 2006a, b). An intermediate Lago Mare episode (Lago Mare 2: ca. $5.500-5.460$ Ma; Fig. 1) is reported only from deep holes in the Mediterranean central basins where it directly overlies the evaporites. It is mainly identified by the occurrence of ostracods of the Cyprideis pannonica group (Iaccarino and Bossio, 1999) but the biofacies is incompletely known. Its significance remains uncertain, usually related to a freshwater input ending the evaporitic phase (OrszagSperber, 2006), which is still unsatisfactorily documented.

Here we present a revision of a new locality of Lago Mare deposit near Malaga (Fig. 2), described by Guerra-Merchán et al. (2008, 2010). Detailed biostratigraphic analysis of these deposits and of the classical Lago Mare localities near Sorbas (Fig. 2B; Civis et al., 1979; Roep and Van Harten, 1979) and Níjar (Fig. 2B; Aguirre and Sánchez-Almazo, 2004; Bassetti et al., 2006) have allowed us to revise the age, depositional environments and stratigraphic location with respect to the Messinian Erosional Surface of the westernmost Lago Mare deposits around the Mediterranean Sea and to present an up-todate geographic distribution of the three types of Lago Mare.

The conventional Messinian age given to the Lago Mare in the Malaga area led Guerra-Merchán et al. (2010) to consider this deposit as sandwiched between two erosional surfaces. It was thus crucial to clarify which of these surfaces corresponds to the late Messinian sea-level drawdown. Offshore Malaga, the erosion observed underneath the Pliocene series was so intense that Messinian units disappear toward the land while Pliocene sediments directly overlie the Tortonian series near the coastline (Comas et al., 1999: see fig. 8). Therefore, the recognition of the Messinian Erosional 
Surface in the Malaga sections needed a sea-land correlation (using available offshore seismic lines; Fig. 2B) to appear unambiguous.

Fig. 1: Chronotratigraphy of the events related to the Messinian Salinity Crisis in the peripheral and central Mediterranean basins: deposition of evaporites, subaerial and marine erosion, Lago Mare (Bache et al., 2012). Correlations with the 8180 curve from Site 982 from the benthic foraminifer Cibicidoides kullenbergi (Hodell et al., 2001) on which has been established and adjusted the global sea level curve from Miller et al. (2011). Relationships with the Eastern Paratethys are indicated by double arrows (Clauzon et al., 2005; Popescu et al., 2009). Chronology is from Bache et al. (2012) and Manzi et al. (2013). Molluscs: Dr, Dreissenids; L, Lymnocardiids; O, Ostracods; D, Dinoflagellate cysts; F, Foraminifers; N, Calcareous nannofossils.

\section{Lago Mare deposits in the northern coastline of the Alboran Sea}

\subsection{The Malaga Basin}

The Malaga Basin (Fig. 2B) is located above two alpine metamorphic nappes of the Betic Internal Zones (Torres-Roldán, 1979; Sanz de Galdeano and López-Garrido, 1991) above which three successive sedimentary episodes, disrupted by major unconformities, took place during the Neogene (López-Garrido and Sanz de Galdeano, 1999). The older sedimentary phase, comprising postnappe Oligocene to Early Miocene transgressive units (Sanz de Galdeano and López-Garrido, 1991; Serrano et al., 2007), is mostly confined to the northern part of the Malaga Basin (Fig. 2B). After the Burdigalian, the basin remained emerged until the deposition of shallow marine conglomerates, sands and calcarenites attributed to the Tortonian (Sanz de Galdeano and López-Garrido, 1991; Serrano et al., 2007; Guerra-Merchán et al., 2010). Tortonian deposits are unconformably overlain by transgressive Pliocene marine deposits (López-Garrido and Sanz de Galdeano, 1999). 
These Pliocene deposits are composed of coarse-grained deposits passing laterally to blue-grey marls and clays (Sanz de Galdeano and López-Garrido, 1991; López-Garrido and Sanz de Galdeano, 1999). According to these authors, the clayey fine-grained sediments contain planktonic foraminifera assemblages [Hirsutella (Globorotalia) margaritae and Globoconella (Globorotalia) puncticulata] indicating an early or middle Pliocene age (Lourens et al., 2004).

To the North of Malaga (Fig. 2B), the reddish to purplish Lago Mare sediments described by Guerra-Merchán et al. $(2008,2010)$ are exposed near the confluence of the Río Mendelín and Río Guadalmedina (Fig. 2C). The Lago Mare biofacies is attested by the occurrence of bivalves (Dreissena ex gr. rostriformis, Pachydacna, Pontalmyra, Prosodacnomya) and ostracods (Amnicythere sp., Cyprideis agrigentina, Euxinocythere sp., Loxoconcha sp., Tyrrhenocythere pontica, etc.) of Paratethyan- type. Very rare wellpreserved specimens of planktonic and benthic foraminifers have been found in the upper part of the Lago Mare Unit, nonetheless suggesting a marine influence.

Fig. 2: General location maps.

A, Studied area; B, Onshore geological sketch of the northern Alboran Sea with the studied areas (1, Río Mendelín and El Túnel near Malaga; 2, Zorreras near Sorbas; 3, Gafares near Nijar). Thick lines point out the seismic profiles shown in Figures $9 \mathrm{~A}$ and $9 B$ within the available seismic database used for the $3 D$ reconstruction in Figure 9C; $C$, Location map and geological map of the area northward of Malaga.The geological map is from Estévez González and Chamón Cobos (1978). Boxes indicate the studied sections (Rio Mendelin and El Túnel) with the corresponding figures. 
According to Guerra-Merchán et al. (2008 and 2010: figs. 2 and 3):

- An alluvial fan made of conglomerates fills a paleo-valley cut within the metamorphic Betic basement during active tectonic uplift and including the part of the Lago Mare coarse-grained sediments;

- subsequently, Lago Mare Unit is affected by intense erosion linked to tectonic activity of the normal fault, suggesting a phase of sedimentary interruption;

- Zanclean marine sediments onlap this erosional surface.

The Zanclean Unit is composed of yellowish clays which contain, among other foraminifers, Sphaeroidinellopsis spp. and Hirsutella (Globorotalia) margaritae, the latter being more common in the upper part (Fig. 3). According to its continuous reverse polarity, the Río Mendelín section is placed within the paleomagnetic Chron C3r. At last, the Río Mendelín Lago Mare is considered as a transitional unit deposited in a transgressive context leading to the Zanclean marine reflooding (Guerra-Merchán et al., 2010). This assumption is in contradiction with the erosional contact of the Zanclean yellowish clays above the Lago Mare deposits (Guerra-Merchán et al., 2010).

Fig. 3: The studied Río Mendelin section. A, Photograph of the sampled section; B, Log of the section with location of samples 1 to 14 (distance between two successive samples is indicated in Table 1); C, Photograph of the marine-continental transition; D, Log of the marine-continental transition; E, Zoomed photograph of the continuously sampled interval between samples 5 and 6 (samples $a-j$; distance between two successive samples: $10 \mathrm{~cm}$ ).

2.2. The Sorbas and Níjar basins 
The Sorbas and Nijar Basins are intramontane basins developed above metamorphic nappes of the southern Betics (Fig. 2B; Torres-Roldán, 1979; Sanz de Galdeano and Vera, 1992). The sedimentary succession of these two Neogene basins has been intensively analysed during the last decades, leading to contradictory interpretations about the process of the MSC (Ott d'Estevou and Montenat, 1990; Riding et al., 1991; Rouchy and Saint-Martin, 1992; Gautier et al., 1994; Dabrio and Polo, 1995; Krijgsman et al., 2001; Fortuin and Krijgsman, 2003; Aguirre and Sánchez-Almazo, 2004; Bassetti et al., 2006; Braga et al., 2006; Roveri et al., 2009; Bourillot et al., 2010; Omodéo Salé et al., 2012; Clauzon et al., 2009, revised). The sedimentation of the southeastern Betic basins took place in the Serravallian-Tortonian (Sanz de Galdeano and Vera, 1992). The lower Messinian record consists of a thick succession of coarse- and fine-grained deposits subdivided into three members: Azagador, Abad and Cantera (Van de Poel, 1991; Sierro et al., 2001; Fortuin and Krijgsman, 2003). The late Messinian series with a thick evaporitic sequence (Yesares Member) made up of gypsum and clay alternations in both the Sorbas and Nijar basins (Dronkert, 1976) resulting from the first sea-level fall of the MSC (Clauzon et al., 1996; CIESM, 2008).

In the Sorbas Basin, the post-evaporitic sedimentation is also separated from the Messinian gypsums by the Messinian Erosional Surface overlain in some places by chaotic debris flows with large blocks of reworked gypsum (Clauzon et al., revised). Three whitish clayey layers are described within the Zorreras Member (Fig. 4A) which overlies calcareous beds containing a coastal fish (Aphanius crassicaudus), above the Messinian Erosional Surface and the Yesares evaporitic Member (Ott d'Estevou and Montenat, 1990). These whitish layers contain Paratethyan-type fossils (dreissenids, 
lymnocardiids, ostracods) with some coastal foraminifers (Civis et al., 1979; Roep and Van Harten, 1979; Ott d'Estevou and Montenat, 1990). They have been thus considered as Lago Mare biofacies and attributed to the Messinian (Dabrio and Polo, 1995; MartínSuárez et al. 2000; Krijgsman et al., 2001) while an earliest Pliocene age has been foreseen by Ott d'Estevou and Montenat (1990), which is now established by Clauzon et al. (2009, revised).

In the Nijar Basin (Fig. 2B), an erosional surface truncates the evaporitic unit (Fortuin and Krijgsman, 2003) and has been referred to the Messinian Erosional Surface (Omodeo Salé et al., 2012). Within the overlying Feos Formation, a chaotic unit mostly made of reworked gypsum blocks fills the Messinian valley delimited by this erosional surface (Omodeo Salé et al., 2012). This chaotic deposit has been first interpreted as a slump (Fortuin and Krijgsman, 2003), then as a debris flow ascribed to the post-MSC marine reflooding (Bache et al., 2012). At Gafares, several whitish clayey layers are exposed within the Feos Formation (Fig. 4B). They contain Paratethyan-type ostracods (Roep and Van Harten, 1979; Bassetti et al., 2006), rare coastal foraminifers (Aguirre and SánchezAlmazo, 2004) and the same fish species as at Sorbas (Aphanius crassicaudus; de la Chapelle and Gaudant, 1987). These Lago Mare deposits have been also ascribed to the post-evaporitic Messinian (Roep and Van Harten, 1979; Dabrio and Polo, 1995; Krijgsman et al., 2001; Aguirre and Sánchez-Almazo, 2004; Fortuin and Krijgsman, 2003; Bassetti et al., 2006). However, on the basis of a lateral change and interbed with marine deposits, Aguirre and Sánchez-Almazo (2004) suggested that the marine reflooding of the Mediterranean Basin took place prior to the "Zanclean deluge" and questioned the chronostratigraphic significance of the Lago Mare deposits. 
For these basins, we will only pay interest to the Lago Mare deposits and bordering layers, their stratigraphy having recently been re-visited in detail by Clauzon et al. (2009, revised), Roveri et al. (2009), and Omodeo Salé et al. (2012), respectively.

Fig. 4: Lago Mare deposits in the region of Almería. A, View of the Zorreras section, near Sorbas. B, View of the Gafares section, near Nijar. W1, W2, W3: whitish clayey layers; 1, 02, 03: location of the studied sample

\section{Materials and methods}

\subsection{Micropaleontological analyses}

We sampled the concerned sections, to acquire dinoflagellate cysts and/or calcareous nannofossils, which were not investigated during previous studies, and thus gives the opportunity to improve the characterization of both the age and the environment of the Lago Mare deposits:

- 24 samples at Río Mendelín (Figs. 2C); results from a first sampling (samples 114; Fig. 3B), which provided a diversified calcareous nannoflora plus foraminifers and (marine and brackish Paratethyan-type) dinoflagellate cysts, prompted a second sampling at higher resolution between samples 5 and 6 (1 $\mathrm{m}$ of space continuously sampled, $10 \mathrm{~cm}$ of thickness per sample: samples a-j; Fig. 3E) which is known as the richest interval in all types of organisms (the above mentioned microorganisms, plus Paratethyan-type molluscs and ostracods according to Guerra-Merchán et al., 2010);

- 3 samples from the El Túnel locality (Fig. 2C); 
- 13 samples at Zorreras (3 in the clays underlying the whitish clayey layer W1; 4, 3 and 3 in the whitish clayey layers W1, W2 and W3, respectively; Figs. 2B, 4A);

- 5 samples at Gafares (3, 3 and 2 in the whitish clayey layers W1, W2 and W3, respectively; Figs. 2B, 4B).

For the analysis of dinoflagellate cysts, each sample (50 gram of dry sediment) was processed using a standard method (Cour, 1974): cold acid digestion, concentration in $\mathrm{ZnCl}_{2}$ (at density 2.0), and sieving at 10 and $20 \mu \mathrm{m}$. A $50 \mu \mathrm{l}$ volume of residue was mounted within glycerol between coverslip and microscope slide in order to allow rotation of the dinoflagellate cysts. Their identification (at magnification x1000) and counting (at magnification x250) of a minimum of 150 specimens per sample were made on a light microscope. Detailed observations were performed on a ZEISS Ultra-55 Scanning Electron Microscope.

To retain the original sample composition for calcareous nannofossils, smear slides were prepared directly from the untreated sediment. The calcareous nannofloral analysis was performed using a light polarizing microscope at magnification $\mathrm{x} 1600$. The nannofloral taxonomic identification followed Perch-Nielsen (1985) and Young (1998).

Finally, aiming to improve biostratigraphic control, we searched for planktonic foraminifers by sieving at 250-150-63 $\mu \mathrm{m}$ (Río Mendelín: samples a to j and 6).

\subsection{Onshore-offshore stratigraphic analysis}

In addition to new micropaleontological data, our study aims at an onshore-offshore stratigraphic correlation of the late Neogene sedimentary succession of the Malaga area. 
Onshore, we particularly followed the contact between the substratum (Malaguide Complex) and the overlying Neogene sediments. We paid special attention to the sedimentary organization of these Neogene deposits.

Offshore, several stratigraphic analyses were performed on 2D seismic profiles acquired in the southern Spanish margin during the last decades (ALB, AS, EAS and SHLS cruises; Fig. 2B). These studies highlighted the occurrence of six major sequences spanning the Lower Miocene to Quaternary (Jurado and Comas, 1992; Comas et al., 1999). We re-examined the uppermost units I and II (Messinian and Pliocene to Pleistocene; Jurado and Comas, 1992) focusing on their geometry separated by an erosive unconformity, called the M reflector (Comas et al., 1992; Chalouan et al., 1997). The M reflector (e.g. the Messinian Erosional Surface) has been picked and a paleo-bathymetric map of the Messinian erosion has been performed. This paleo-bathymetric map has been depth converted using the average water velocity of $1500 \mathrm{~m} . \mathrm{s}-1$ and $2000 \mathrm{~m} . \mathrm{s}-1$ for the Pliocene and Quaternary sediments (Comas et al., 1996).

\section{Results}

Our micropaleontological analyses concern the three kinds of protists belonging to phytoplankton (dinoflagellates, coccoliths) or zooplankton (foraminifers), respectively. They are used in onshore-ooffshore correlations.

\subsection{Dinoflagellate cysts}


Dinoflagellate cysts have been identified in six of the thirty-two samples gathered from the Lago Mare deposits in the Río Mendelín section (samples a, b, e, f, h, 6; Fig. 5). However, no dinoflagellate cysts have been observed in the Zorreras and Gafares sections. Among the 26 recorded taxa, 14 are marine species, 12 are brackish of Paratethyan-type. One specimen of Radiosperma corbiferum (marine to brackish microorganism) has been recorded in sample b (Fig. 5). In addition, Pediastrum (freshwater green alga) has been recorded in samples e, f, h and 6 (Fig. 5). Reworked dinoflagellate cysts (mostly from Lower-Middle Miocene) have been found, more frequently in samples where freshwater input is indicated by Pediastrum (Fig. 5).

Fig. 5: Dinoflagellate cysts recorded in the Río Mendelin section, grouped according to their ecological significance. Synthetic diagram shows the relative abundance of the groups: 1, marine taxa (white line separates stenohaline species to the left from euryhaline taxa to the right); 2, brackish taxa (black line separates Galeacysta etrusca to the left from the other taxa to the right); 3, indeterminable plus indeterminate cysts; 4 , freshwater taxa. Spiniferites spp. are indicated both as marine and brackish taxa. They are mostly made of fragments which prohibit a species ascribtion but can be ecologically classified according to their morphology.

Dinoflagellate cysts and other taxa have been grouped into their ecological requirements (Londeix et al., 2007; Popescu et al., 2009; Zonneveld et al., 2013), as follows (Fig. 5):

- marine species: Impagidinium aculeatum, I. patulum, Spiniferites delicatus, S. membranaceus, S. mirabilis (stenohaline species: oceanic - outer shelf); Achomosphaera andalousiensis, Homotryblium spp., Lingulodinium machaerophorum, Nematosphaeropsis labyrinthus, Operculodinium centrocarpum, cysts of Pentapharsodinium dalei, Spiniferites bentorii, $S$. bulloideus, S. ramosus, (euryhaline species: inner shelf - coastal - lagoonal); 
- brackish taxa (Paratethyan-type): Galeacysta etrusca, Impagidinium globosum, Millioudodinium punctatum, M. pelagicum, Pyxidinopsis psilata, Pontiadinium inequicornutum, P. pecsvaradense, P. obesum, Spiniferites balcanicus, S. bentorii oblongus, S. bentorii pannonicus, S. cruciformis, S. maisensis, S. tihanyensis;

- marine to brackish species: Radiosperma corbiferum;

- freshwater taxon: Pediastrum sp.

A synthetic diagram summarizes the relative abundance of the dinoflagellate cysts groups (Fig. 5):

- marine stenohaline species fluctuate between 5.3 and $14.3 \%$, with a maximum in sample $f$, indicating some increase of oceanic water influx;

- marine euryhaline taxa show a relative abundance between 10 and $34 \%$, with maximum in sample $\mathrm{h}$, where cosmopolitan species of Spiniferites (i.e., $S$. ramosus and S. bulloideus) developed;

- high percentages of Paratethyan-type taxa (53-84\%), mostly dominated by Galeacysta etrusca (21-28) accompanied by Pontiadinium spp. (3-11\%) and fragments of Spiniferites spp., the morphology of which allows to refer to brackish affinities (2-15\%);

- indeterminable cysts (because of poor preservation) and indeterminate cysts (often fragments of cysts) show relative abundance around 4\%, except in sample $\mathrm{h}$ where they reach $10 \%$;

- Pediastrum, freshwater element, transported by rivers, is scarce $(0.9-4 \%)$, reaching $4 \%$ in sample $\mathrm{h}$. 
This dinoflagellate cyst assemblage highlights the marine conditions of the Lago Mare deposits in the Río Mendelín section. Several well-preserved specimens of Galeacysta etrusca are shown in Figure 6.

\subsection{Calcareous nannofossils}

A calcareous nannoflora, more or less well-preserved, has been observed in the Lago Mare deposits of the Río Mendelín section (Fig. 3B; samples 1, 2, 3, 5, 6, 9 and 10). Triquetrorhabdulus rugosus is the only biostratigraphic marker recorded in sample 1 (Table 1). In samples 5, 6 and 10, the calcareous nannoflora is particularly diversified (Table 1) and displays Triquetrorhabdulus rugosus and Ceratolithus acutus (Fig. 7). Nannoplankton assemblages include reworked specimens (from Cretaceous to Miocene) which are not mentioned in the figures. A calcareous nannoflora has also been found in samples 11 to 13 , especially in sample 12 where Ceratolithus acutus and Triquetrorhabdulus rugosus are also present. In addition, a calcareous nannoflora has been found in the three samples gathered from the El Túnel locality (Table 1) and may be ascribed to the NN12a nannoplankton subzone based on the occurrence of T. rugosus in sample 2 (Fig. 1; Raffi et al., 2006; Melinte-Dobrinescu et al., 2009).

Fig. 6: Photographs of some specimens of Galeacysta etrusca recorded in the Lago Mare deposits of the Rio Mendelin section: views $c, d$ and f are from sample e; views $g$ and $h$ are from sample f; views $a, b$ and $e$ are from sample 6 . View $a$, note the occurrence of $a$ cyst of Pediastrum close to G. etrusca. Scale bar: $20 \mu \mathrm{m}$.

All samples gathered from the three whitish clayey layers of the Zorreras section (Sorbas Basin) are barren. However, the three samples from the clays immediately underlying the basal whitish clayey layer W1 (Fig. 4A) contain a nannoflora including 
Ceratolithus acutus and Triquetrorhabdulus rugosus (Table 1) which is thus ascribed to the early NN12b nannoplankton subzone (Fig. 1; Raffi et al., 2006; Melinte-Dobrinescu et al., 2009). In addition, underlying laminated beds (Fig. 4A) which, in a nearby section, yielded remains of the fish Aphanius crassicaudus (a fossil species considered as living in costal marine to brackish waters; Gaudant and Ott d'Estevou, 1985), also contain $C$. acutus and T. rugosus (Clauzon et al., revised). These whitish layers thus deposited later than the marine sediments in this area.

Three samples taken from the lowermost whitish clayey layer W1 of the Gafares section (Níjar) are barren. A calcareous nannoflora containing Ceratolithus acutus as biostratigraphic marker (Table 1) has been recorded in the second whitish clayey layer W2 (sample 1) and can be ascribed to the late NN12b nannoplankton subzone (Fig. 1; Raffi et al., 2006; Melinte-Dobrinescu et al., 2009). In the overlying whitish clayey layer W3, sample 4 contains some calcareous nannofossils but not biostratigraphic markers (Table 1). Twenty seven metres above, Ceratolithus acutus has also been observed in a clay layer where Hirsutella (Globorotalia) margaritae was pointed out by Bassetti et al. (2006). In this area, the upper whitish layers W2 and W3 were still influenced by marine waters.

Fig. 7: Photographs of some specimens of Ceratolithus acutus (crossed Nichols) recorded in the Lago Mare deposits of the Río Mendelín section: $a$ and b, sample 5; c, sample 6. Scale bar: $5 \mu \mathrm{m}$.

\subsection{Planktonic foraminifers}


Planktonic foraminifers have been recorded in samples a to $\mathrm{f}$ and 6 from the Lago Mare deposits of the Río Mendelín section (Fig. 3). The foraminiferal assemblage in samples a to f shows a poor to diversified marine assemblage composed amongst others of Globigerina decoraperta, G. praebulloides, Globigerinita glutinata, Globoturborotalita (Globigerina) nepenthes, Neogloboquadrina acostaensis (sinistral and dextral coiling) and $N$. incompta. Only the Globoturborotalita (Globigerina) nepenthes species (recorded in samples a and f) has biostratigraphic significance (ranging from 11.63 to 4.37 Ma, i.e. from latest Serravallian to mid-Zanclean; Lourens et al., 2004).

4.4. Onshore-offshore stratigraphic analysis: the occurrence of Gilbert-type fan deltas

At El Túnel locality (Fig. 2C), an erosional surface is particularly well-exposed on the metamorphic Betic basement (Fig. 8A-C). This surface is overlain by a steep southdipping deltaic complex. The sedimentation starts with somewhat large subrounded blocks followed by conglomeratic to sandy foreset beds. These foreset beds are laterally replaced by silty-clayey bottomset beds in which the samples were taken (Fig. 8C). This sedimentary pattern is characteristic of the subaqueous unit of a Gilbert-type fan delta in its proximal part (Clauzon, 1990) as usually observed within the Messinian valleys around the Mediterranean Basin (Clauzon et al., 1990; Suc et al., 1992; Bache et al., 2012) and its appendices, such as the Dacic Basin in the Paratethys (Clauzon et al., 2005; Suc et al., 2011; Bache et al., 2012). The marine nature of the Guadalmedina Gilbert-type fan delta is attested by a calcareous nannoflora (Table 1), devoid of precise 
biostratigraphic marker, except Triquetrorhabdulus rugosus (highest occurrence at 5.279 Ma; Fig. 1; Raffi et al., 2006) obtained in three samples from the bottomset beds at El Túnel (Table 1). As a consequence, the clayey sediments exposed at the Río Mendelín section might be considered as the basinward extension of the bottomset beds observed at El Túnel. However, the Río Mendelín series is also nested within the metamorphic basement and begins with conglomeratic to sandy foreset beds which laterally pass to the dominantly clayey Lago Mare sediments (Fig. 8D). This secondary prograding sedimentary system must hence be regarded as a small size Gilbert-type fan delta tributary of the larger Guadalmedina Gilbert-type fan delta. This is in agreement with the geological map of the area which suggests two coalescing fans (Fig. 2C; Estévez González and Chamón Cobos, 1978). Based on the recognition of NN12a and b calcareous nannofloras (in the Río Mendelín and El Túnel sections), the Guadalmedina Gilbert-type fan delta is dated from the latest Messinian to earliest Zanclean (Fig. 1), consistently with the occurrence of Globoturborotalia (Globigerina) nepenthes in the Lago Mare sediments (Río Mendelín). As a consequence, the erosional surface observed at El Túnel (Fig. 8A, B) is the MES which can also be followed up to the Río Mendelín section (Fig. 8D) and corresponds to the peak of the MSC (Fig. 2C). The Río Mendelín section is topped by reddish conglomerates (Fig. 3C, D) which have been ascribed to Quaternary (Guerra-Merchán et al., 2010). They are made of rounded pebbles which attest to their alluvial origin. They are separated from the underlying bottomset beds (yellowish clays) by an almost horizontal (15 cm thick) white marly layer without any sign of erosion at its top (Fig. 3C, D). We thus consider that there is no sedimentary gap in the succession from the yellowish clays to the reddish conglomerates that we interpret 
as the topset beds of the Gilbert-type fan delta (i.e. its subaerial unit). The conglomeratic topset beds of the Mediterranean Zanclean Gilbert-type fan deltas are commonly red as shown in Figure 4 for the Zorreras Member of the Sorbas Basin. We interpret the underlying white marly layer (Fig. 3C, D) as the marine-continental transition which, with the MES, is one of the morphological features of a Mediterranean Zanclean Gilberttype fan delta (for more detail, see: Bache et al., 2012: figure 2). This prograding sedimentary filling is the result of the post-MSC marine reflooding of the Mediterranean Basin which transformed the Messinian fluvial valleys into marine rias (Clauzon et al., 1990; Bache et al., 2012). Then, it has then been affected by the Quaternary erosion of the Guadalmedina and Mendelín rivers, and does not currently superimpose their respective Messinian valleys (Fig. 2C), a current phenomenon described as the “aggradation epigenesis” (Clauzon, 1999; Clauzon et al., revised).

Fig. 8: The Gilbert-type fan delta of the Guadalmedina River (Malaga). A, Detailed view of the Messinian Erosional Surface separating the Gilbert-type fan delta deposits from the metamorphic basement. B, Photograph of a part of view $C$ at greater magnification. $C$, View of the proximal part of the Gilbert-type fan delta showing (1) the coarse blocks and the conglomeratic to sandy foreset beds overlying the Messinian Erosional Surface (MES) and the metaporphic basement, and (2) the sampled bottomset beds. D, Panoramic view of the Río Mendelín section

The MES observed at El Túnel can be followed off the Iberian margin on seismic profiles (Figs. 2B, 9). Its identification offshore is based on correlations with previous seismic stratigraphy studies (Jurado and Comas, 1992; Comas et al., 1999; Martínez del Olmo and Comas, 2008) and biostratigraphic analyses from the Alboran A1 and ODP 976 holes (Fig. 2B; Comas et al., 1999; Serrano et al., 1999; Siesser and de Kaenel, 1999). 
The MES is characterized by the angular unconformity separating the Miocene from Pliocene sediments (Campillo et al., 1992; Alonso et al., 1999; Comas et al., 1999). The seismic profile EAS-7, almost perpendicular to the coast and in continuation with the Pliocene rias observed onshore (Río Guadalhorce and Río Guadalmedina; Fig. 9C), displays southward prograding Pliocene sediments over the angular unconformity (Fig. 9A). The southward progradation of the Pliocene deposits is marked by the succession of downlap terminations on the MES (red arrows in Figure 9A). Analysis of the seismic profile EAS-82, perpendicular to EAS-7, displays the sharp geometry of the MES reflector and the morphology of a $8 \mathrm{~km}$ wide valley filled by Pliocene sediments (Fig. 9B). Offshore Malaga, the sediments immediately overlying the MES have been dated in two wells (ODP Site 976 and the industrial Alboran A1 borehole) on the basis of the lowest occurrence of the planktonic foraminifer Hirsutella (Globorotalia) margaritae. Such a datation of the post-MSC marine reflooding suffers from an insufficient precision because (1) samples of both sections have not been studied at an appropriate resolution, and (2) calcareous nannofossils have not been searched out. Moreover, it has recently been highlighted that (1) the date of the lowest occurrence of $H$. (G.) margaritae in the Mediterranean is somewhat inconsistent (Fig. 1; Lourens et al., 2004; Clauzon et al., revised), and (2) the right biostratigraphic marker of the post-MSC marine reflooding is the calcareous nannofossil Ceratolithus acutus which is generally recorded in the Mediterranean sections below $H$. $(G$.) margaritae. The post-MSC marine reflooding is coeval from the basin to the margins, i.e. it occurred in the latest Messinian according to our results (those presented here and from many other Mediterranean localities: MelinteDobrinescu et al., 2009; Clauzon et al., 2009, revised). However, aware of a possible 
confusion, and waiting for new reliable data from the Alboran offshore sections, we will use in this paper "Pliocene" to describe the deposits overlying the MES offshore by contrast with the underlying "Miocene" ones, consistently with the available literature.

Using all the seismic profiles indicated in Figure 2B, the MES has systematically been picked to reconstruct the paleo-bathymetry of the Messinian valley (Fig. 9C). The Messinian valley is followed over tens of kilometers toward the centre of the basin where its course and termination have been described by Estrada et al. (2011).

Fig. 9: Morphology of the Messinian Erosional Surface in the area of Malaga, from land to the Alboran Basin. A1 and A2, Offshore non interpreted and interpreted seismic profile EAS-7, respectively; $B 1$ and B2, Offshore non interpreted and interpreted seismic profile EAS-82, respectively; $C$, Reconstructed paleo-bathymetry of the Messinian Erosional Surface, obtained from seismic data interpolation.

\section{Discussion}

Our results indicate that: (1) the Lago Mare layers were deposited under marine conditions; (2) their lowermost part (samples 1-4) may belong to the NN12a nannoplankton subzone based on the occurrence of Triquetrorhabdulus rugosus, and (3) their upper part (samples 5-12) belongs to the nannoplankton subzone NN12b with respect to the co-occurrence of $C$. acutus and T. rugosus (Fig. 1; Raffi et al., 2006; Melinte-Dobrinescu et al., 2009). We will first develop our thought about the origin and mode of transport of the Paratethyan-type organisms, before discussing the sedimentary specificity of the Río Mendelín Lago Mare and its setting in the context of the Lago Mare 
biofacies in southern Spain then with respect to their distribution in the whole Mediterranean region.

\subsection{Origin and mode of transport of the Paratethyan-type organisms.}

These questionings narrowly linked, several times discussed (see for a large review: Orszag-Sperber, 2006), need to be re-examined to highlight our results and specify our interpretations. We have used 'Paratethyan-type' for describing the characteristic organisms of the Lago Mare biofacies in order to avoid an a priori link to an unquestionable origin from the Paratethys. Concerning brackish molluscs, foraminifers and ostracods of 'marine' origin, a doubt has been introduced for a long time on the significance of their occurrence in isolated Holocene hyposaline environments, distant from the sea, in North Africa (Gasse et al., 1987; Plaziat, 1993). To explain such examples, transport by birds was considered which was hence proposed for Lago Mare fossils too (see: Orszag-Sperber, 2006, and references therein), making such paleoenvironments the host of an endemic life (Bassetti et al., 2006). Transportation by birds seems improbable in the case of dinoflagellates because of fragility to oxydation of their encysted forms while their motile forms live few hours. According to high number of dinoflagellate cyst records before and after the MSC both in the Mediterranean and Paratethys, there is no doubt on the occurrence of Galeacysta etrusca in brackish Paratethyan environments prior to the Mediterranean Lago Mare sediments (see: Popescu et al., 2009, and references therein). If Paratethyan-type organisms were transported by birds, how to explain, particularly for Lago Mare 1 and 3, that such events are concentrated in a so short time-window (some $300 \mathrm{kyrs}$, from about 5.640 to $5.332 \mathrm{Ma}$; 
Fig. 1) and have been never repeatedly reported in the so deeply investigated past environments of the Mediterranean. It is clear that, at the state of our knowledge, the easiest way for transportation of so many organisms was a direct but temporary connection between the Mediterranean and Paratethys through a marine gateway, the location of which may have sifted along time. Concerning the late Messinian and early Zanclean, this assumption is strongly supported by geological data through the Balkans (Popescu et al., 2009; Bache et al., 2012) and the record of marine organisms (foraminifers, coccoliths, dinoflagellates) in the Dacic Basin (Clauzon et al., 2005; Suc et al., 2011).

The Paratethyan-type (usually considered as brackish) dinoflagellate cyst Spiniferites cruciformis is reported from a Late Quaternary freshwater lake in northern Greece (Kouli et al., 2001). The authors consider that this environment corresponded to the usual ecology of this species. We must emphasize that this is an isolated example which requires to be confirmed, as this species can adapt to environment changes in developing various morphologies. We repeatedly found Spiniferites cruciformis in our analyses associated with Galeacysta etrusca, the Paratethyan origin of which and its brackish ecology being above re-affirmed.

As a consequence, we will then consider that the Paratethyan-type organisms constituting the Lago Mare biofacies have an actual Paratethyan origin and that their transportation into the Mediterranean was forced by water currents, except for the Lago Mare 2 event which requires to be studied in more detail.

\subsection{Sedimentary context of the Río Mendelín Lago Mare}


According to Guerra-Merchán et al. (2010), the Pliocene deposits of the northern area of Malaga fill a valley cut within the Betic metamorphic basement that we undoubtedly ascribe to the peak of the MSC (Fig. 2C). Based on micropaleontological and stratigraphic analyses, we have shown that the Lago Mare deposits of the Río Mendelín section also belong to the submarine part of a Gilbert-type fan delta, and more precisely of a tributary of the Río Guadalmedina. Guerra-Merchán et al. $(2008,2010)$ indicate an erosional truncation, marked by a conglomeratic accumulation, which separates their $\mathrm{Pl}-1$ Unit (dated as Zanclean) from the underlying Lago Mare Unit, interpreted as late Messinian. This truncation is well-observed in Figure 3A and clearly separates the yellowish sediments from the underlying reddish ones in Figure 3B. Because of the occurrence of some normal faults in the Lago Mare deposits (see Fig. 3A, B), GuerraMerchán et al. (2010) "suggest a phase of sedimentary interruption" to explain the unconformity "probably caused by a relative base-level fall, tectonic in origin, before the marine Pliocene flooding". The coastal marine environment that we identified in the Lago Mare deposits, and particularly the occurrence of Ceratolithus acutus in these sediments, challenge this interpretation, leading us to ascribe deposition of the entire Río Mendelín section as a consequence of the marine reflooding ending the MSC. Consequently, these channel-like features, separated by an erosional surface, may result from submarine gravity instabilities and/or slope processes frequently described along continental margins (Brunt et al., 2013; Dakin et al., 2013). They can also be found in deltaic contexts where they are usually described as slope channels (Porębski and Steel, 2003). Such features are frequent in the clayey deposits within the Mediterranean Zanclean rias (Fig. 10) where they may cause impressive erosive truncations outlined by conglomeratic accumulations 
such as at Saint-Isidore (Var Valley, southern France; Fig. 10A; Clauzon et al., 1990). There, channelization was accentuated by the submarine confluence of a tributary Gilbert-type fan delta with that of the Var River, maybe in a context of small sea-level variations. Such conditions have probably prevailed in the Malaga area just after the marine reflooding of the Mediterranean Basin.

Fig. 10: Submarine erosional morphologies affecting bottomset and foreset beds of Zanclean Gilbert-type fan deltas in Southern France. A, General view of the Saint-Isidore quarry (Nice area); B, Saint-Isidore: detail of an erosional contact; C, General view of the Pichegu quarry (Arles area).

North of Malaga, the post-MSC marine reflooding in the Río Mendelín and Río Guadalmedina rias is evidenced by the development of conglomeratic foreset beds at the apex of the Gilbert-type fan delta and the presence of calcareous nannofossils in the earliest clayey bottomset beds at El Túnel (Table 1). According to Bache et al. (2012), the catastrophic marine reflooding of the Mediterranean Basin caused by the collapse of the Gibraltar sill occurred at 5.460 Ma, i.e. in correspondence with the high global sea level that Miller et al. (2011) match with the Marine Isotopic Stage TG 11 (Hodell et al., 2001) as shown in Figure 1. Then, the occurrence of well-preserved mollusc shells in the Lago Mare Unit of the Río Mendelín section suggests an evolution toward more coastal conditions with the development of lagoons while marine microorganisms continued to contribute to the micropaleontological assemblage. Such evolution is interpreted as resulting from a slight fall in global sea level which, in addition, may have caused some erosion of the Lago Mare Unit (Fig. 1). After 5.345 Ma (lowest occurrence of 
Ceratolithus acutus; Fig. 1; Raffi et al., 2006), a sea-level rise may have favoured submarine erosion within the bottomset beds. Figure 11 illustrates such a paleogeographic and sedimentological evolution, starting from the fluvial erosional phase during the peak of the MSC and ending with the deposition of the yellowish clays containing Hirsutella (Globorotalia) margaritae. Paleogeographic and sedimentological changes that affected the region of Malaga in the latest Miocene and earliest Pliocene appear to have been mainly forced by sea-level fluctuations. The effect of tectonics mentioned by Guerra-Merchán et al. (2010) on the basis of small-scale normal faults in the Lago Mare deposits must be questioned. Considering the rapid succession of the two submarine channels, these small-scale, local normal faults can be considered as synsedimentary faulting probably due to overloading with a very limited impact. Offshore Malaga, the interpolated map of the MES illustrates the morphology of the junction of the Guadalhorce and Guadalmedina Messinian valleys filled by Pliocene prograding sediments (Fig. 9C).

Fig. 11: Reconstructed paleogeographic and sedimentological evolution of the area northward of Malaga during and after the peak of the MSC (see Fig. 1 for the time schedule). A, At the time of the Mediterranean desiccation (5.600 Ma) when Rio Guadalmedina and Río Mendelín cut their valley; B, When the Mediterranean basin was reflooded by marine waters transforming the fluvial valleys into marine rias $(5.460 \mathrm{Ma})$, allowing the onset of Gilbert-type fan delta progradation; C, During a slight sea-level fall at ca. 5.360 Ma leading a bay paleogeography in the Río Mendelín ria with occurrence of some lagoons where molluscs of Paratethyan-type developed, the shells of which deposited in the bottomset beds; D, During the following sea-level rise (at ca. 5.350-5.332 Ma) resulting in increased development of Gilbert-type fan deltas and clayey bottomset beds affected by submarine erosion. 
To summarize, our results and interpretations contrast with those of Guerra-Merchán et al. $(2008,2010)$ on the following major items:

- the significant erosion which impacted the Betic basement was the direct consequence of the Mediterranean Sea-level drawdown during the peak of the MSC;

- this erosion is not locally limited but is continuously followed down to the deepest Alboran Sea;

- if the Lago Mare Unit of Río Mendelín really belongs to the latest Messinian, it however must be ascribed to the $3^{\text {rd }}$ Lago Mare event which immediately followed the post-MSC marine reflooding of the Mediterranean Basin;

- the Río Mendelín Lago Mare Unit is a part of a Gilbert-type fan delta where the dip of conglomeratic-sandy beds has a sedimentary origin and is not tectonically forced;

- the discontinuity separating the Lago Mare Unit from Pl-1 Unit results from submarine gravity instabilities commonly observed in such deltaic systems and cannot be considered as expressing the regional tectonic activity.

In the Sorbas Basin, the marine clays post-dating the MSC and dated in many places by Ceratolithus acutus and Triquetrorhabdulus rugosus calcareous nannofossils, either comprise the bottomset beds of Gilbert-type fan deltas in their proximal location or the basinward extension of these bottomset beds (Clauzon et al., 2009, revised). In some localities, such as at Zorreras hill (Fig. 4A), these marine clays are immediately overlain by the lower whitish clayey layers (i.e. Lago Mare deposits) of the Zorreras Member overlying the marine-continental transition. 
In the Nijar Basin, specifically at Gafares, the Lago Mare whitish clayey layers belong to the Feos Formation (Bassetti et al., 2006) which is the local equivalent of the Zorreras Formation in the Sorbas Basin (Fortuin and Krijgsman, 2003). They are part of a continental series affected by some repeated marine influxes (Aguirre and SánchezAlmazo, 2004; Bassetti et al., 2006; Omodeo Salé et al., 2012).

Accordingly, the Lago Mare deposits studied in southern Spain clearly belong to the post-MSC sedimentary infilling process of fluvial valleys cut during the peak of the crisis. Such sedimentary successions refer to Gilbert-type fan deltas (including some minor tributary ones) in the proximal areas of the Messinian valleys, which started to develop in the latest Messinian and continued during the Zanclean (Fig. 1).

\subsection{Biofacies of Lago Mare deposits in southern Spain}

The Lago Mare deposits of Río Mendelín are characterized by their high biological diversity and occurrence of biota having a biostratigraphic and paleoecological significance. In addition to the usual occurrence of both Paratethyan molluscs (Dreissena ex. gr. rostriformis, Pachydacna, Pontalmyra partschi, Melanopsis narzolina, Theodoxus mutinensis, etc.) and ostracods (Amnicythere accicularia, Loxocauda limata, Loxoconcha kochi, Tyrrhenocythere pontica, etc.), they contain a rich Paratethyan dinoflagellate cyst assemblage (Galeacysta etrusca, Spiniferites cruciformis, S. bentori pannonicus, etc.). The presence of calcareous nannofossils and planktonic foraminifers together with Paratethyan and marine dinoflagellate cysts suggest a deposition under an influx of marine waters. Such an influx must have occurred during a period of high sea level which allowed the connection between Mediterranean and Paratethys basins. The co-occurrence 
of Paratethyian microorganisms living in surface water (dinoflagellates) with ostracods and molluscs support this scenario. Indeed, such a fossil assemblage with brackish organisms (dinoflagellates, ostracods, molluscs) and marine ones (dinoflagellates, foraminifers, coccoliths) has been recorded in several places around the Mediterranean from deposits usually ascribed to Lago Mare (Casabianda in Corsica, Eraclea Minoa in Sicily, Maccarone in northern Italy, Trilophos in northern Greece, and Intepe in Turkey; Fig. 12; see Table 2 for references), to which we must add deposits from the Dacic Basin characterized by Paratethyan organisms and affected by Mediterranean water influxes (Fig. 12; Table 2). Specific environments (small bays receiving some fluvial input, for example) at the interface between brackish and marine conditions must be considered. The reject of marine organisms, regarded a priori as reworked, has often masked the reality of these biotopes relatively complex to visualize (for a striking example, see: Popescu et al., 2007).

Fig. 12: Selected localities in the Mediterranean and Eastern Paratethys illustrating the three Lago Mare events. The probable gateway between the Aegean Sea and the Eastern Paratethys is indicated by a grey double arrow. Localities from West to East (references for the Mediterranean localities with Lago Mare biofacies are given in Table 2): 1, Río Mendelin; 2, Zorreras; 3, Gafares; 4, Cuevas del Almanzora; 5, Site 978; 6, Monforte, Colmenar, Oami; 7, Papiol; 8, Site 124 ; 9, Site 975; 10, Site 372; 11, Théziers; 12, SaintMarcel d'Ardèche; 13, Saint-Restitut; 14, Allex; 15, Sioneri; 16, Casabianda; 17, Djebel Herageg; 18, Torre Sterpi; 19, Site 653; 20, Site 132; 21, Cava Serredi; 22, Monteglino; 23, Monticino; 24, Site 974; 25, Pomarance; 26, Eraclea Minoa; 27, Maccarone; 28, Capo Rossello; 29, Pasquasia; 30, Ancone; 31, Civitella del Tronto; 32, Vizzini; 33, Zinga; 34, Site 374; 35, Kavvadades; 36, Agios Sostis; 37, Turnu Severin; 38, Hinova; 39, Gabrovačka Reka; 40, Drăcevo; 41, Ticleni; 42, Trilophos; 43, Badislava; 44, Souvala; 45, Skini; 46, Khairetiana; 47, Doiceşti; 48, Bizdidel; 49, Mesi; 50, Site 969; 51, Faneromeni; 52, Călugăreni; 53, Argova Valley; 54, Valea Vacii; 55, Intepe; 56, Site 129; 57, Yalakdere; 58, Site 380; 59, Site 376; 60, Site 967; 61, Site 968; 62, Giolou; 63, Kerc. 
The NN12a-b nannoplankton age indicates that this event immediately followed the marine reflooding of the Mediterranean Basin and its re-connection with the Paratethys, dated around 5.460 Ma (Bache et al., 2012). This event predated the Zanclean Global Stratotype Section and Point (GSSP) set at 5.332 Ma (Van Couvering et al., 2000; Lourens et al., 2004). In fact, the so-called "Zanclean Deluge" occurred in the latest Messinian time. The Lago Mare event recorded in the Malaga area is the third Lago Mare event shown in Figure 1. The Río Mendelín Lago Mare correlates with the Arenazzolo Unit of Sicily which, there, is separated from the underlying Lago Mare Unit (in fact the Lago Mare event 1; Fig. 1) by an angular discordance illustrating a discontinuity (Popescu et al., 2009; Bache et al., 2012) that we re-interpret now as the reflooding surface rather than the Messinian Erosional Surface, with a maintained sedimentary gap of 140 kyrs $(5.600-5.460 \mathrm{Ma})$ between the two units. The yellowish clays of Río Mendelín correlate with the Sicilian Trubi Formation. The Lago Mare event 3 signals momentarily renewed water exchanges between the Mediterranean and the Eastern Paratethys after the peak of the MSC and the marine reflooding of the Mediterranean at 5.460 Ma (Fig. 1; Clauzon et al., 2005; Popescu et al., 2009; Suc et al., 2011; Bache et al., 2012). According to Guerra-Merchán et al. (2010), Paratethyan molluscs are restricted to the lower part of the reddish silts and marls in the Río Mendelín section while Paratethyan ostracods disappear in its upper part (Fig. 3), probably due to a salinity increase. The Hirsutella (Globorotalia) margaritae species, more frequently recorded at the base of the overlying yellowish clays (Fig. 3), is referred by Guerra-Merchán et al. (2010) to the first common occurrence level of the species which is also dated at 5.080 
Ma by Lourens et al. (2004). However, this level is significantly oldier than $5.080 \mathrm{Ma}$ because of the co-occurrence of $H$. (G.) margaritae with Ceratolithus acutus and Triquetrorhabdulus rugosus (Table 1). An age comprised between 5.345 Ma (lowest occurrence of C.acutus) and 5.279 Ma (highest occurrence of T. rugosus) must hence be considered for this level at Río Mendelín (Fig. 1; Raffi et al., 2006). H. (G.) margaritae may have entered the Mediterranean Basin prior to $5.080 \mathrm{Ma}$ (see also Clauzon et al., revised, for the same evidence in the Sorbas Basin further East), consistently with its first appearance at 6.080 Ma in the nearby Atlantic Ocean (Lourens et al., 2004) and the reflooding age of the Mediterranean Basin proposed at 5.460 by Bache et al. (2012). The co-occurrence of brackish (Paratethyan) molluscs and ostracods with marine microorganisms (calcareous nannofossils, foraminifers, dinoflagellate cysts) in Lago Mare deposits has been questioned (Iaccarino and Bossio, 1999). However it seems conceivable to consider that the marine microorganisms (calcareous nannofossils, dinoflagellate cysts, foraminifers) plus the Paratethyan-type dinoflagellate cysts were deposited in situ in such a coastal open marine environment. After their arrival in the area brought by marine currents, the Paratethyan ostracods and molluscs would have become established in a small bay with very close coastal lagoons to explain the excellent preservation of mollusc shells which did not suffer a fluvial transport. Such an environment would have been temporarily invaded by marine waters given the repeated occurrences of marine dinoflagellate cysts (Fig. 5), calcareous nannofossils (Table 1) and some planktonic foraminifers.

The Lago Mare deposits described in the Sorbas and Níjar basins (i.e. the whitish clayey layers) are part of dominantly continental complexes, called the Zorreras Member 
and the Feos Formation, respectively. In the Sorbas Basin, the lower whitish clayey layer (W1) overlies marine clays containing Ceratolithus acutus and Triquetrorhabdulus rugosus (i.e. of the NN12b nannoplankton subzone) (Clauzon et al., 2009, revised), as shown at the Zorreras hill (Fig. 4A; Table 1). In some areas of the Sorbas Basin, the same clays underlying the Zorreras Member contain also Hirsutella (Globorotalia) margaritae (Clauzon et al., revised). At the Zorreras hill, dinoflagellate cysts and calcareous nannofossils have not been recorded. This may suggest that this layer is the marginal marine (lagoonal) signature of the Lago Mare, following the marine invasive episode. A similar conclusion can be expressed about the Lago Mare deposits exposed in the Níjar Basin where dinoflagellate cysts and calcareous nannofossils have not been recorded in the lowermost whitish clayey layer. And yet, calcareous nannofossils have been recorded at the base of W2 and W3 (Fig. 4B; Table 1), that allows to discard a preservation or taphonomic bias between these identical facies. In fact, as proposed by Clauzon et al. (2005) and Popescu et al. (2007, 2009), the record of Paratethyan dinoflagellate cysts is the actual chronologically well-constrained signature of the Paratethyan water influx (as samples a, b, e, f, h and 6 from the Río Mendelín section). The record of Paratethyan molluscs and/or ostracods constitutes sometimes a coeval indication of Lago Mare conditions (as in the Río Mendelín section) or, more often, as a slightly postponed and more continental archive (lagoons) of influx by Paratethyan waters and organisms (see also: Aguirre and Sánchez-Almazo, 2004).

5.4. Distribution of Lago Mare deposits in the Mediterranean region 
This study allows us to complete the listing (Table 2) and distribution map (Fig. 12) of the three kinds of Lago Mare deposits (1, 2, and 3; Fig. 1) where the major change concerns the chronologic location of these deposits from eastern Andalusia (Lago Mare 3). Indeed, these Lago Mare deposits were previously reported as belonging to the Lago Mare 1 event (Clauzon et al., 2005: fig. 13). Our investigations establish that they are to be referred to the Lago Mare 3 event, a result which is in agreement with the previous assumptions made at Sorbas by Ott d'Estevou and Montenat (1990) and Níjar by Aguirre and Sánchez-Almazo (2004). A questionment persists for the Lago Mare deposits in the Bajo Segura Basin (sites Monforte, Colmenar, and Oami: locality 6 in Figure 12), only documented by ostracods, which is considered as laterally equivalent to gypsums (Soria et al., 2007, 2008), i.e. to be ascribed to Lago Mare 1 (Fig. 5; Table 2). Here, the stratigraphic organisation described by Soria et al. $(2007,2008)$ is greatly similar to that observed near Malaga with, in addition, residual gypsums, the relationship of which with the Lago Mare deposits is unclear all the more so as layers with calcareous nannofossils of Zone NN12 are indicated below the gypsums (Soria et al., 2008: figure 2).

The examination of Figure 12 points out that Lago Mare 3 episode has the largest Mediterranean extension to the West (except the enigmatic locality 6, see above), at least up to Malaga, especially concentrated along the northern coastlines. Such a geographic distribution of the Lago Mare 3 localities is striking. This means that, in the Early Pliocene:

- a significant input of brackish Paratethyan surface waters flowed into the Mediterranean Basin, as suggested by Sprovieri et al. (2008), probably through the 
Balkan Corridor (Fig. 12) proposed by Clauzon et al. (2005), Popescu et al. (2009), Suc et al. (2011) and Bache et al. (2012);

- a surface geostrophic current ran along the Northwestern Mediterranean shoreline, as suggested by Suc and Drivaliari (1991).

It can be considered that, fastly after the post-MSC marine reflooding, a marine thermohaline circulation almost similar to the present one became established, at least in the Western Mediterranean Basin (Poulain et al., 2012). Such a circulation seems to have benefited from an active incursion by Paratethyan waters (Sprovieri et al., 2008). Seismic and stratigraphic analyses performed on Pliocene to Quaternary sequences (Juan et al., 2012) showed that since the opening of the Gibraltar Strait, the circulation model of the Alboran Sea is quite similar to the present one. After the Zanclean reflooding, sedimentation was dominated by contourite deposition locally interrupted by turbiditic fans and slope deposits (Juan et al., 2012). A different and less intensive current pattern before the peak of the MSC might explain the weakness of the influx of Paratethyan surface waters into the Western Mediterranean. The Lago Mare 2 episode appears insufficiently documented, especially regarding the contribution of dinoflagellate cysts and calcareous nannoplankton. Accordingly, its understanding cannot be considered as having been achieved.

\section{Conclusion}

Owing to new micropaleontological findings and stratigraphic onshore-offshore analysis, we revised in detail the age and depositional environment of Lago Mare 
deposits for three localities in southern Spain (Malaga, Sorbas and Níjar) and the following conclusions were established:

1) North of Malaga, the Lago Mare exposed along the Río Mendelín results from the third episode of invasion of Paratethyan organisms into the Mediterranean, corresponding to a two-way water exchange at high sea level between the basins (Lago Mare 3). The paleontological interpretations have been enhanced by investigations into the Paratethyan and Mediterranean dinoflagellate cysts and calcareous nannofossils. Age constraints have been refined by nannofossil biostratigraphy and onshore-offshore identification of the Messinian Erosional Surface overlain by a Gilbert-type fan delta. A paleogeographic and sedimentary reconstruction of the Malaga area for the time-interval 5.600-5.332 Ma shows that a minor fall in sea level facilitated the development of the Lago Mare biofacies after the marine reflooding ending the Messinian Salinity Crisis.

2) In the Sorbas and Nijar basins, the Lago Mare deposits belong to the continental sedimentary unit overlying the marine sediments of the Mediterranean reflooding, yet still affected by marine incursions at Níjar, i.e. in a more coastal location. They also illustrate the Lago Mare 3 episode, but their biofacies lacks Paratethyan dinoflagellate cysts.

3) In addition to their chronostratigraphic distinction, this paleoenvironmental criterion separates the Malaga Lago Mare from the Sorbas and Níjar ones. Indeed, only a Lago Mare biofacies including Paratethyan dinoflagellate cysts may be considered as the precise influx level of Paratethyan waters. In contrast, those Lago Mare biofacies only composed of Paratethyan molluscs and/or ostracods must be regarded as the marginalmarine (lagoonal) signature subsequent to the invasive episode. 
Our data and resulting conclusions thus evidence a new environmental, sedimentological and stratigraphic context for the Lago Mare deposits of the peripheral basins of the northern Alboran Sea.

An up-to-date review of the Lago Mare evidence confirms that three invasive episodes occurred within the time-interval 5.700-5.300 Ma and supports the conclusion that the concept of a unique chronostratigraphic unit must be abandoned. The geographic distribution of Lago Mare 3 suggests that the modern pattern of Mediterranean currents took place after the marine reflooding at 5.460 Ma. At last, the petroleum interest of Lago Mare 3 is reaffirmed.

\section{Acknowledgements}

Field trips and micropaleontological analyses have been supported by the CIFRE PhD grant $N^{\circ} 584 / 2010$ (TOTAL/UPMC) and by the CNRS/INSU “Actions Marges” Program. The authors gratefully aknowledge Gemma Ercilla (ICM-CSIC, Barcelona) for constructive discussion. We also warmly thank the ICM-CSIC laboratory in Barcelona for multi- and single-channel seismic profiles (available http://www.icm.csic.es/geo/gma/SurveyMaps/ and http://www.igme.es/internet/sistemas_infor/BASESINTERNET/sigeof.htm).

We particularly thank M.J. Head for his friendly review of the manuscript and edition of the English, two anonymous reviewers and I. Csato, Associate Editor of the journal, who significantly contributed to improve the mansucript. 


\section{References}

Aguirre, J., Sánchez-Almazo, I.M., 2004. The Messinian post-evaporitic deposits of the Gafares area (Almeria-Níjar basin, SE Spain). A new view of the "Lago-Mare" facies. Sedimentary Geology 168, 71-95.

Almera, J., 1894. Descripción de los terrenos pliocénicos de la cuenca del Bajo Llobregat y Llano de Barcelona. Mapa Geológico de la Provincia de Barcelona, 351 pp.

Alonso, B., Ercilla, G., Martínez-Ruiz, F., Baraza, J., Galimont, A., 1999. PliocenePleistocene sedimentary facies at Site 976: depositional history in the northwestern Alboran Sea. In: R. Zahn, M.C. Comas, A. Klaus (Eds.), Leg 161, Proceedings of the Ocean Drilling Program, Scientific Results 161, 57-68.

Archambault-Guézou, J., 1976. Présence de Dreissenidae euxiniques dans les dépôts à Congéries de la vallée du Rhône et sur le pourtour du bassin méditerranéen. Implications biogéographiques. Bulletin de la Société Géologique de France ser. 7, 18 (5), 1267-1276.

Bache, F. Popescu, S.-M., Rabineau, M., Gorini, C., Suc, J.-P., Clauzon, G., Olivet, J.-L., Rubino, J.-L., Melinte-Dobrinescu, M.C., Estrada, F., Londeix, L., Armijo, R., Meyer, B., Jolivet, L., Jouannic, G., Leroux, E., Aslanian, D., Dos Reis, A.T., Mocochain, L., Dumurdžanov, N., Zagorchev, I., Lesić, V., Tomić, D., Çağatay, M.N., Brun, J.-P., Sokoutis, D., Csato, I., Ucarkus, G., Çakir, Z., 2012. A two-step process for the reflooding of the Mediterranean after the Messinian Salinity Crisis. Basin Research 24, $125-153$. 
Ballesio, R., 1972. Etude stratigraphique du Pliocène rhodanien. Documents du Laboratoire de Géologie de la Faculté des Sciences de Lyon 53, 1-333.

Bassetti, M.A., Miculan, P., Sierro, F.J., 2006. Evolution of depositional environments after the end of Messinian Salinity Crisis in Níjar basin (SE Betic Cordillera). Sedimentary Geology 188-189, 279-295.

Benson, R.H., 1973. Psychrospheric and continental ostracoda from ancient sediments in the floor of the Mediterranean. Kaneps, A.G. (Ed.), Leg 13, Initial Reports of the Deep Sea Drilling Project 13 (1), 1002-1008.

Benson, R.H., 1976. Changes in the ostracodes of the Mediterranean with the Messinian salinity crisis. Palaeogeography, Palaeoclimatology, Palaeoecology 20, 147-170.

Benson, R.H., 1978. The paleoecology of the ostracodes of DSDP Leg 42A. In: Kidd, R.B., Worstell, P.J. (Eds.), Leg 42, Initial Reports of the Deep Sea Drilling Project 42 (1), 777-787.

Bertini, A., 1992. Palinologia ed aspetti ambientali del versante Adriatico dell'Appennino centro-settentrionale durante il Messiniano e lo Zancleano. PhD Thesis, University of Florence, $88 \mathrm{pp}$.

Bertini, A., 2006. The Northern Apennines palynological record as a contribute for the reconstruction of the Messinian palaeoenvironments. Sedimentary Geology 188-189, $235-258$.

Bertini, A., Corradini, D., Suc, J.-P., 1995. On Galeacysta etrusca and the connections between the Mediterranean and the Paratethys. Romanian Journal of Stratigraphy 76, supplement 7 (1), 141-142. 
Blanc-Valleron, M.-M., Rouchy, J.-M., Pierre, C., Badaut-Trauth, D., Schuler, M., 1998. Evidence of Messinian nonmarine deposition at Site 968 (Cyprus lower slope). In: Robertson, A.H.F., Emeis, K.-C. et al. (Eds.), Leg 160, Proceedings of the Ocean Drilling Program, Scientific Results 160, 437-445.

Bonaduce, G., Sgarrella, F., 1999. Paleoecological interpretation of the latest Messinian sediments from southern Sicily (Italy). Memorie della Società Geologica d'Italia 54, 83-91.

Bossio, A., Esteban, M., Giannelli, L., Longinelli, A., Mazzanti, R., Mazzei, R., Ricci Lucchi, F., Salvatorini, G., 1978. Some aspects of the Upper Miocene in Tuscany. Messinian Seminar, 4, Rome, Pacini (Ed.), Pisa, 88 pp.

Bossio, A., Giannelli, L., Mazzanti, R., Mazzei, R., Salvatorini, G., 1981. Gli strati alti del Messiniano, il passaggio Miocene-Pliocene e la sezione plio-pleistocenica di Nugola nelle colline a NE del Monti Livornesi. 9th Congress of the Società Paleontologica Italiana, Excursion guide-book, Pacini (Ed.), Pisa, 55-90.

Bourillot, R., Vennin, E., Rouchy, J.M., Blanc-Valleron, M.M., Caruso, A., Durlet C., 2010. The end of the Messinian Salinity Crisis in the western Mediterranean: Insights from the carbonate platforms of south-eastern Spain. Sedimentary Geology $229,224-253$.

Braga, J.C., Martín, J.M., Riding, R., Aguirre, J., Sánchez-Almazo, I., Dinarès-Turell, J., 2006. Testing models for the Messinian salinity crisis: The Messinian record in Almería, SE Spain. Sedimentary Geology 188-189, 131-154. 
Brunt, R.L., Hodgson, D.M., Flint, S.S., Pringle, J.K., Di Celma, C., Prélat, A., Grecula, M., 2013. Confined to unconfined: Anatomy of a base of slope succession, Karoo Basin, South Africa. Marine and Petroleum Geology 41, 206-221.

Burollet, P.F., 1952. Porto Farina. Carte géologique de la Tunisie au 1/50.000ème, 7.

Campillo, A.C., Maldonado, A., Mauffret, A., 1992. Stratigraphic and tectonic evolution of the western Alboran Sea: Late Miocene to recent. Geo-Marine Letters $12(2), 165-172$.

Carbonnel, P., 1978. La zone à Loxoconcha djaffarovi SCHNEIDER (Ostracoda, Miocène supérieur) ou le Messinien de la vallée du Rhône. Revue de Micropaléontologie 21 (3), 106-118.

Carloni, G., Francavilla, F., Borsetti, A.M., Cati, F., D’Onofrio, S., Mezzetti, R., Savelli, C., 1974. Ricerche stratigrafiche sul limite Miocene-Pliocene nelle Marche centro-meridionali. Giornale di Geologia ser. 2, 39 (2), 363-392.

Carnevale, G., Caputo, D., Landini, W., 2006a. Late Miocene fish otoliths from the Colombacci Formation (Northern Apennines, Italy): Implications for the Messinian 'Lago-mare' event. Geological Journal 41, 1-19.

Carnevale, G., Landini, W., Sarti, G., 2006b. Mare versus Lago-mare : marine fishes and the Mediterranean environment at the end of the Messinian Salinity Crisis. Journal of the Geological Society, London 163, 75-80.

Cavallo, O., Repetto, G., 1988. Un nuovo giacimento della facies a Congerie nell'Albese. Rivista Piemontese di Storia Naturale 9, 43-62. 
Chalouan, A., Saji, R., Michard, A., Bally A.W., 1997. Neogene tectonic evolution of the southwestern Alboran basin as inferred from seismic data off Morocco. Bulletin of the American Association of Petroleum Geologists 81, 1161-1184.

Chapelle, G. de la, Gaudant, J., 1987. Découverte de deux nouveaux gisements de poissons fossiles messiniens dans le bassin de Níjar-Carboneras (Andalousie orientale): signification paléoécologique et implications paléogéographiques. Estudios Geológicos 43, 279-297.

CIESM (Antón, J., Çağatay, M.N., De Lange, G., Flecker, R., Gaullier, V., GundeCimerman, N., Hübscher, C., Krijgsman, W., Lambregts, P., Lofi, J., Lugli, S., Manzi, V., McGenity, T.J., Roveri, M., Sierro, F.J., Suc J.-P.), 2008. Executive Summary. In: Briand, F. (Ed.), The Messinian Salinity crisis from mega-deposits to microbiology - A consensus report. CIESM Workshop Monographs 33, 7-28.

Cita, M.B., Colombo, L., 1979. Sedimentation in the latest Messinian at Capo Rossello (Sicily). Sedimentology 26, 497-522.

Cita, M.B., Santambrogio, S., Melillo, B., Rogate, F., 1990. Messinian paleoenvironments: new evidence from the Tyrrhenian Sea (ODP Leg 107). In: Kastens, K.A., Mascle, J. et al. (Eds.), Leg 107, Proceedings of the Ocean Drilling Program, Scientific Results 107, 211-227.

Cita, M.B., Stradner, H., Ciaranfi, N., 1973. Studi sul Pliocene e sugli strati di passagio dal Miocene al Pliocene. III. Biostratigraphical investigations on the Messinian stratotype and on the overlying "Trubi" Formation. Rivista Italiana di Paleontogia 79 (3), 393-446. 
Cita, M.B., Vismara Schilling, A., Bossio, A., 1980. Studi sul Pliocene e sugli strati di passagio dal Miocene al Pliocene. XII. Stratigraphy and paleoenvironment of the Cuevas del Almanzora section (Vera basin). A re-interpretation. Rivista Italiana di Paleontologia 86 (1), 215-240.

Cita, M.B., Wright, R.C., Ryan, W.B.F., Longinelli, A., 1978. Messinian paleoenvironments. In: Kidd, R.B., Worstell, P.J. (Eds.), Leg 42, Initial Reports of the Deep Sea Drilling Project 42 (1), 1003-1035.

Civis, J., Martinell, J., De Porta, J., 1979. Presencia de Cyprideis pannonica pseudoagrigentina DECIMA en el Miembro Zorreras (Sorbas, Almería). Studia Geologica 15, 57-62.

Clauzon, G., 1990. Restitution de l'évolution géodynamique néogène du bassin du Roussillon et de l'unité adjacente des Corbières d'après les données écostratigraphiques et paléogéographiques. Paléobiologie Continentale 17, 125-155. Clauzon, G., 1999. L'impact des variations eustatiques du bassin de Méditerranée occidentale sur l'orogène alpin depuis 20 Ma. Etudes de Géographie Physique 28, $1-8$.

Clauzon, G., Suc, J.-P., Aguilar, J.-P., Ambert, P., Cappetta, H., Cravatte, J., Drivaliari, A., Doménech, R., Dubar, M., Leroy, S., Martinell, J., Michaux, J., Roiron, P., Rubino, J.-L., Savoye, B., Vernet, J.-L., 1990. Pliocene geodynamic and climatic evolutions in the French Mediterranean region. Paleontologia i Evolucio Spec. Mem. 2, 132-186.

Clauzon, G., Suc, J.-P., Melinte-Dobrinescu, M.C., Jouannic, G., Jolivet, L., Rubino, J.-L., Popescu, S.-M., Gorini, C., Bache, F., Estrada, F., 2009. New insights from the 
Andalusian Sorbas and Vera basins. 13th RCMNS Congress, Naples, Acta Naturalia de L'Ateneo Parmense 45 (1-4), 334-335.

Clauzon, G., Suc, J.-P., Do Couto, D., Jouannic, G., Melinte-Dobrinescu, M.C., Jolivet, L., Quillévéré, F., Lebret, N., Mocochain, L., Popescu, S.-M., Martinell, J., Doménech, R., Rubino, J.-L., Gumiaux, C., Warny, S., Bellas, S.M., Gorini, C., Bache, F., Rabineau, M., Estrada, F., revised. New insights on the Sorbas Basin (SE Spain): the onshore reference of the Messinian Salinity Crisis. Basin Research.

Clauzon, G., Suc, J.-P., Gautier, F., Berger, A., Loutre, M.-F., 1996. Alternate interpretation of the Messinian salinity crisis: Controversy resolved? Geology 24 (4), $363-366$.

Clauzon, G., Suc, J.-P., Popescu, S.-M., Mărunţeanu, M., Rubino, J.-L., Marinescu, F., Melinte, M.C., 2005. Influence of the Mediterranean sea-level changes over the Dacic Basin (Eastern Paratethys) in the Late Neogene. The Mediterranean Lago Mare facies deciphered. Basin Research 17, 437-462.

Colalongo, M.L., 1968. Ostracodi del neostratotipo del Messiniano. Giornale di Geologia ser. 2, 35 (2), 67-72.

Colalongo, M.L., 1988. Planktic foraminifer biostratigraphy, with remarks on benthic foraminifers and ostracodes (Monticino quarry Faenza). In: De Giuli, C., Vai, G.B. (Eds.), Fossil vertebrates in the Lamone valley, Romagna Apennines, International Workshop on Continental faunas at the Miocene-Pliocene Boundary. Field Trip Guidebook, Faenza, pp. 53-54.

Comas, M.C., García-Dueñas, V., Jurado, M.J., 1992. Neogene tectonic evolution of the Alboran Sea from MCS data. Geo-Marine Letters 12, 157-164. 
Comas, M.C., Platt, J.P., Soto, J.I., Watts, A.B., 1999. The origin and tectonic history of the Alboran basin: insights from Leg 161 results. In: R. Zahn, M.C. Comas, A. Klaus (Eds.), Leg 161, Proceedings of the Ocean Drilling Program, Scientific Results 161, 555-580.

Comas, M.C., Zahn, R., and Klaus, A., Aubourg, C., Belanger, P.E., Bernasconi, S.M., Cornell, W., de Kaenel, E.P., de Larouzière, F.D., Doglioni, C., Doose, H., Fukusawa, H., Hobart, M., Iaccarino, S.M., Ippach, P., Marsaglia, K., Meyers, P., Murat, A., O'Sullivan, G.M., Platt, J.P., Prasad, M., Siesser, W.Q., Skilbeck, C.G., Soto, J.I., Tandon, K., Torii, M., Tribble, J.S., Wilkens, R.H., 1996. Proceedings of the Ocean Drilling Program, Initial Reports 161, 179-297.

Corradini, D., Biffi, U., 1988. Etude des dinokystes à la limite Messinien-Pliocène dans la coupe Cava Serredi, Toscane, Italie. Bulletin des Centres de Recherche Exploration-Production Elf-Aquitaine 12 (1), 221-236.

Corselli, C., Grecchi, G., 1984. The passage from hypersaline to hyposaline conditions in the Mediterranean Messinian: discussion of the possible mechanisms triggering the "lago-mare" facies. Paléobiologie Continentale 14 (2), 225-239.

Cosentino, D., Gliozzi, E., Pipponzi, G., 2007. The late Messinian Lago-Mare episode in the Mediterranean Basin: Preliminary report on the occurrence of Paratethyan ostracod fauna from central Crete (Greece). Geobios 40, 339-349.

Cour, P., 1974. Nouvelles techniques de détection des flux et de retombées polliniques: étude de la sédimentation des pollens et des spores à la surface du sol. Pollen et Spores 16, 1, 103-141. 
Dabrio, C.J., Polo, M.D., 1995. Oscilaciones eustáticas de alta frequencia en el Neógeno superior de Sorbas (Almería, sureste de España). Geogaceta 18, 75-78.

Dakin, N., Pickering, K.T., Mohrig, D., Bayliss, N.J., 2013. Channel-like features created by erosive submarine debris flows: Field evidence from the Middle Eocene Ainsa Basin, Spanish Pyrenees. Marine and Petroleum Geology 41, 62-71.

Decima, A., Sprovieri, R., 1973. Comments on late Messinian microfaunas in several sections from Sicily. In: Messinian events in the Mediterranean (Ed. by C.W. Drooger), Koninklijke Nederlandse Akademie Van Wetenschappen, Geodynamics Science Report 7, 229-234.

Di Geronimo, I., Esu, D., Grasso, M., 1989. Gli strati a "Congerie" del Messiniano superiore del margine nord-occidentale Ibleo. Caratteristiche faunistiche e possibli implicazioni paleogeografiche e paleoclimatiche. Atti dell'Academia Peloritana dei Pericolanti 67, supplement 1, 129-150.

Dronkert, H., 1976. Late miocene evaporites in the Sorbas Basin and adjoining aeras. Memorie della Società Geologica Italiana 16, 341-361.

Estévez González, C., Chamón Cobos, C., 1978. Malaga - Torremolinos. Mapa geologico de España (1:50,000) ser. 2, 1053, IGME, Madrid.

Estrada, F., Ercilla, G., Gorini, C., Alonso, B., Vazquez, T., J., Garcia-Castellanos, D., Juan, C., Maldonado, A., Ammar, A., Elabbassi, M., 2011. Impact of pulsed Atlantic water inflow into the Alboran Basin at the time of the Zanclean flooding. GeoMarine Letters 31, 361-376.

Esu, D., Taviani, O., 1989. Oligohaline mollusc faunas of the Colombacci Formation (Late Messinian) from an exceptional fossil vertebrate site in the Romagna 
Apennines: Monticino quarry (Brisighella, N Italy). Bollettino della Società Paleontologica Italiana 28, 265-270.

Fontannes, F., 1883. Note sur l'Extension et la Faune de la mer pliocène dans le sudest de la France. Bulletin de la Société Géologique de France ser. 3, 11, 103-142.

Fortuin, A.R., Krijgsman, W., 2003. The Messinian of the Nijar Basin (SE Spain): sedimentation, depositional environments and paleogeographic evolution. Sedimentary Geology 160, 213-242.

Gasse, F., Fontes, J.C., Plaziat, J.C., Carbonel, P., Kaczmarska, I., De Deckker, P., Soulié-Marsche, I., Callot, Y., Dupeuble, P.A., 1987. Biological remains, geochemistry and stable isotopes for the reconstruction of environmental and hydrological changes in the Holocene lakes from North Sahara. Palaeogeography, Palaeoclimatology, Palaeoecology 60, 1-46.

Gaudant, J., Ott d'Estevou, P., 1985. Première découverte d'Aphanius crassicaudus (Agassiz) (poisson téléostéen, Cyprinodontidae) dans le Messinien post-évaporitique d'Andalousie. Estudios Geológicos 41, 93-98.

Gautier, F., Clauzon, G., Suc, J.P., Cravatte, J., Violanti, D., 1994. Age et durée de la crise de salinité messinienne. Comptes Rendus de l'Académie des Sciences de Paris ser. 2, 318, 1103-1109.

Gignoux, M., 1950. Géologie stratigraphique, 4th edition, Masson (Ed.), Paris, 735 pp.

Gillet, H., Lericolais, G., Réhault, J.-P., 2007. Messinian event in the black sea: Evidence of a Messinian erosional surface. Marine Geology 244, 142-165.

Gillet, S., 1937. Sur la présence du Pontien sensu stricto dans la région de Salonique. Comptes-Rendus de l'Académie des Sciences de Paris 205, 1243-1245. 
Gillet, S., 1960. Observations sur de jeunes coquilles de Mollusques du Pliocène saumâtre du Llobregat (Barcelone). Bulletin de la Société Géologique de France ser. 7, $1,731-733$.

Gillet, S., 1965. Los Limnocardidos del Plioceno de Papiol (Barcelona). Memorias y Comunicaciones ser. 2, 1, 3-81.

Gillet, S., 1968. La faune messinienne des environs d'Ancona. Giornale di Geologia ser. 2, 36, 69-100.

Gillet, S., Geissert, F., 1971. La faune de mollusques du Pontien de Trilophos (SW de Thessaloniki). Annales Géologiques des Pays Helléniques ser. 1, 23, 123-164.

Gillet, S., Gramann, F., Steffens, P., 1978. Neue biostratigraphische Ergebnisse aus dem brackischen Neogen an Dardanellen und Marmara-Meer (Türkei). Newsletters on Stratigraphy 7 (1), 53-64.

Guerra-Merchán, A., Serrano, F., Garcés, M., Gofas, S., Esu, D., Gliozzi, E., Grossi, F., 2010. Messinian Lago-Mare deposits near the Strait of Gibraltar (Malaga Basin, S Spain). Palaeogeography, Palaeoclimatology, Palaeoecology 285, 264-276.

Guerra-Merchán, A., Serrano, F., Garcés, M., Gofas, López Garrido, A.C., El Kadiri, K., Hlila, R., 2008. Caracterización de la sedimentación Lago Mare (Messiniense terminal) y de la transgresión del comienzo del Plioceno en la cuenca de Málaga (Cordillera Bética). Geogaceta 44, 207-210.

Hodell, D.A., Curtis, J.H., Sierro, F.J., Raymo, M.E., 2001. Correlation of late Miocene to early Pliocene sequences between the Mediterranean and North Atlantic. Paleoceanography 16, 2, 164-178. 
Hsü, K.J., 1978. Correlation of Black Sea sequences. In: D.A. Ross, Y.P. Neprochnov (Eds.), Leg 42. Initial Report of the Deep Sea Drilling Project 42, 2, 489-497.

Hsü, K.J., Cita, M.B., Ryan, W.B.F., 1973. The origin of the Mediterranean evaporites. In: Kaneps, A.G. (Ed.), Leg 13, Initial Reports of the Deep Sea Drilling Project 13 (2), $1203-1231$.

Iaccarino, S.M., Bossio, A., 1999. Paleoenvironment of uppermost Messinians equences in the Western mediterranean (Sites 974, 975, and 978). In: Zahn, R., Comas, M.C., Klaus, A. (Eds.), Proceedings of the Ocean Drilling Program, Scientific Results 161, $529-541$.

Iaccarino, S., Papani, G., 1979. Il Messiniano dell'Appennino settentrionale dalla Val d'Arda alla Val Secchia: stratigrafia e rapporti con il substrato e il Pliocene. In: Step, G. (Ed.), Volume dedicato a Sergio Venzo, University of Parma, 15-46.

Juan, C., Ercilla, G., Estrada, F., Casas, D., Alonso, B., García, M., Farran, M., Palomino, D., Vázquez, J. T., Llave, E., Hernández-Molina, F.J., Medialdea, T., Gorini, C., D’Acremont, E., El Moumni, B., Gensous, B., Tesson, M., Maldonado, A., Ammar A. and CONTOURIBER \& MONTERA TEAMS, 2012. Contourite sedimentation in the Alboran Sea: Plio-Quaternary evolution. Geo-Temas, 13.

Jurado, M.J., Comas, M.C., 1992. Well log interpretation and seismic character of the cenozoic sequence in the northern Alboran Sea, Geo-Marine Letters, 12 (2), 129-136.

Kontopoulos, N., Zelilidis, A., Piper, D.J.W., Mudie, P.J., 1997. Messinian evaporites in Zakynthos, Greece. Palaeogeography, Palaeoclimatology, Palaeoecology 129, 361-367. Kouli, K., Brinkhuis, H., Dale, B., 2001. Spiniferites cruciformis: a fresh water dinoflagellate cyst? Review of Palaeobotany and Palynology 113, 273-286. 
Krijgsman, W., Fortuin, A.R., Hilgen, F.J., Sierro, F.J., 2001. Astrochronology for the Messinian Sorbas basin (SE Spain) and orbital (precessional) forcing for evaporite cyclicity. Sedimentary Geolology 140, 43-60.

Krijgsman, W., Stoica, M., Vasiliev, I., Popov, V.V., 2010. Rise and fall of the Paratethys Sea during the Messinian Salinity Crisis. Earth Planetary Science Letters 290, 183-191.

Londeix L., Benzakour M., Suc J.-P., Turon J.-L., 2007. Messinian paleoenvironments and hydrology in Sicily (Italy): The dinoflagellate cyst record. Geobios 40 (3), 233-250. López-Garrido, A.C., Sanz de Galdeano, C., 1999. Neogene sedimentation and tectonoeustatic control of the Malaga Basin, South Spain. Journal of Petroleum Geology 22, $81-96$.

Lourens, L.J., Hilgen, F.J., Laskar, J., Shackleton, N.J., Wilson, D., 2004. The Neogene period. In: Gradstein, F.M., Ogg, J.G., Smith, A.G. (Eds.), A geological Time Scale 2004. Cambridge University Press, Cambridge, pp. 409-440.

Magné, J., Orszag-Sperber, F., Pilot, M.-D., 1977. Nouvelles données sur le Pliocène de Corse: le problème de la limite Miocène-Pliocène. Bulletin du Bureau de Recheches Géologiques et Minières ser. 2, section 1, 3, 209-218.

Manzi, V., Gennari, R., Hilgen, F., Krijgsman, W., Lugli, S., Roveri, M., Sierro, F.J., 2013. Age refinement of the Messinian salinity crisis onset in the Mediterranean. Terra Nova 25, 315-322.

Marabini, S., Vai, G.B., 1988. Geology of the Monticino Quarry, Brisighella, Italy. Stratigraphic implications of its late Messinian mammal fauna. In: De Giuli, C., Vai, G.B. (Eds.), Fossil Vertebrates in the Lamone Valley, Romagna Apennines - Field Trip Guidebook, Faenza, 39-57. 
Martín-Suárez, E., Freudenthal, M., Krijgsman, W., Fortuin, A.R., 2000. On the age of the continental deposits of the Zorreras Member (Sorbas Basin, SE Spain). Geobios 33, $505-512$.

Martina, E., Casati, P., Cita, M.B., Gersonde, R., D’Onofrio, S., Bossio, A., 1979. Notes on the Messinian stratigraphy of the Crotone basin, Calabria (Italy). Annales Géologiques des Pays Helléniques special issue, 2, 755-765.

Martínez del Olmo, W., Comas, M.C., 2008. Arquitectura sísmica, olistostromas y fallas extensionales en el norte de la cuenca oeste del Mar de Albrán. Revista de la Sociedad Geologica de Espana, 21, 151-167.

Mărunţeanu, M., Papaianopol, I., 1995. The connection between the Dacic and Mediterranean Basins based on calcareous nannoplankton assemblages. Romanian Journal of Stratigraphy 76 (7), 169-170.

Mărunţeanu, M., Papaianopol, I., 1998. Mediterranean calcareous nannoplankton in the Dacic Basin. Romanian Journal of Stratigraphy 78, 115-121.

Melinte-Dobrinescu, M.C., Suc, J.-P., Clauzon, G., Popescu, S.-M., Armijo, R., Meyer, B., Biltekin, D., Çağatay, M.N., Ucarkus, G., Jouannic, G., Fauquette, S., Çakir, Z., 2009. The Messinian Salinity Crisis in the Dardanelles region: Chronostratigraphic constraints. Palaeogeography, Palaeoclimatology, Palaeoecology 278, 24-39.

Miller, K.G., Mountain, G.S., Wright, J.D., Browning, J.V., 2011. A 180-Million-Year Record of Sea Level and Ice Volume Variations. Oceanography 24, 2, 40-53.

Omodeo Salé, S., Gennari, R., Lugli, S., Manzi, V., Roveri, M., 2012. Tectonic and climatic control on the Late Messinian sedimentary evolution of the Nijar Basin (Betic Cordillera, Southern Spain). Basin Research, 24, 314-337. 
Orszag-Sperber, F., 2006. Changing perspectives in the concept of "Lago-Mare" in Mediterranean Late Miocene evolution. Sedimentary Geology 188-189, 259-277.

Ott d'Estevou, P., Montenat, C., 1990. Le bassin de Sorbas - Tabernas. Documents et travaux IGAL 12-13, 101-128.

Pellen, R., 2011. La Crise de Salinité Messinienne dans l'avant-fosse apenninique. Master SML - Géosciences Océan, Université de Bretagne Occidentale, 32 pp.

Perch-Nielsen, K., 1985. Cenozoic calcareous nannofossils. In: Bolli, H.M., Saunders, J.B., Perch-Nielsen, K. (Eds.), Plankton Stratigraphy, Cambridge University Press, Cambridge, pp. 427-554.

Pilot, M.-D., Brébion, P., Lauriat-Rage, A., 1975. Les gisements fossilifères du Néogène récent et du Quaternaire de la région d'Aleria-Vadina. Bulletin de la Société des Sciences Historiques et Naturelle de la Corse 615-616, 62-74.

Plaziat, J.-C., 1993. Modern and fossil potamids (Gastropods) in saline lakes. Journal of Paleolimnology 8, 163-169.

Popescu, S.-M., Krijgsman, W., Suc, J.-P., Clauzon, G., Mărunţeanu, M., Nica, T., 2006. Pollen record and integrated high-resolution chronology of the Early Pliocene Dacic Basin (Southwestern Romania). Palaeogeography, Palaeoclimatology, Palaeoecology $238(1-4), 78-90$.

Popescu, S.-M., Suc, J.-P., Melinte, M.-C., Clauzon, G., Quillévéré, F., Sütő-Szentai, M., 2007. Earliest Zanclean age for the Colombacci and uppermost Di tetto formations of the "latest Messinian" northern Apennines: New palaeoenvironmental data from the Maccarone section (Marche Province, Italy). Geobios 40 (3), 359-373. 
Popescu, S.-M., Dalesme, F., Jouannic, G., Escarguel, G., Head, M.J., MelinteDobrinescu, M.C., Sütö-Szentai, M., Bakrac, K., Clauzon, G., Suc, J.-P., 2009. Galeacysta etrusca complex, dinoflagellate cyst marker of Paratethyan influxes into the Mediterranean Sea before and after the peak of the Messinian Salinity Crisis. Palynology 33 (2), 105-134.

Porębski, S.J., Steel, R.J., 2003. Shelf-margin deltas: their stratigraphic significance and relation to deepwater sands. Earth-Science Reviews 62, 283-326.

Poulain, P.-M., Menna, M., Mauri, E., 2012. Surface Geostrophic Circulation of the Mediterranean Sea Derived from Drifter and Satellite Altimeter Data. Journal of Physical Oceanography 42, 973-990.

Raffi, I., Backman, J., Fornaciari, E., Pälike, H., Rio, D., Lourens, L., Hilgen, F., 2006. A review of calcareous nannofossil astrobiochronology encompassing the past 25 million years. Quaternary Science Reviews 25, 3113-3137.

Riding, R., Martin, J.M., Braga, J.C., 1991. Coral-stromatolite reef framework, Upper Miocene, Almería, Spain. Sedimentology 38, 799-818.

Roep, Th.B., Van Harten, D., 1979. Sedimentological and ostracodological observations on Messinian post-evaporite deposits of some southeastern Spanish basins. Annales Géologiques des Pays Helléniques special issue, 3, 1037-1044.

Rögl, F., Bernor, R.L., Dertmizakis, M.D., Müller, C., Stancheva, M., 1991. On the Pontian correlation in the Aegean (Aegina Island). Newsletters on Stratigraphy 24 (3), $137-158$.

Rouchy, J.-M., Orszag-Sperber, F., Blanc-Valleron, M.-M., Pierre, C., Rivière, M., Combourieu-Nebout, N., Panayides, I., 2001. Paleoenvironmental changes at the 
Messinian-Pliocene boundary in the Eastern Mediterranean (southern Cyprus basins): significance of the Messinian Lago-Mare. Sedimentary Geology 145, 93-117.

Rouchy, J.M., Saint-Martin, J.P., 1992. Late Miocene events in the Mediterranean as recorded by carbonate-evaporite relations. Geology 20, 629-632.

Roveri, M., Gennari, R., Lugli, S., Manzi, V., 2009. The Terminal Carbonate Complex: the record of sea-level changes during the Messinian salinity crisis. GeoActa 8, 63-77.

Ruggieri, G., 1962. La serie marina pliocenica e quaternaria della Val Marecchia. Atti dell'Academia di Scienze, Lettere e Arti di Palermo 19, 1-169.

Sanz de Galdeano, C., López Garrido, A.C., 1991. Tectonic evolution of the Malaga Basin (Betic Cordillera). Regional implications. Geodinamica Acta 5, 173-186.

Sanz de Galdeano, C., Vera, J.A., 1992. Stratigraphic record and palaeogeographical context of the Neogene basins in the Betic Cordillera, Spain. Basin Research, 4, 21-36.

Selli, R., 1973. An outline of the Italian Messinian. In: Messinian events in the Mediterranean (Ed. by C.W. Drooger), Koninklijke Nederlandse Akademie Van Wetenschappen, Geodynamics Science Report 7, 150-171.

Serrano, F., Gonzalez-Donoso, J.M., Linares, D., 1999. Biostratigraphy and paleoceanography of the Pliocene at Sites 975 (Menorca Rise) and 976 (Alboran Sea) from a quantitative analysis of the planktonic foraminiferal assemblages. In: R. Zahn, M.C. Comas, A. Klaus (Eds.), Leg 161, Proceedings of the Ocean Drilling Program, Scientific Results 161, 185-195.

Serrano, F., Guerra-Merchán, A., Kadiri, K.E., Sanz de Galdeano, C., Garrido, A.C.L., Martin-Martin, M., Hlila, R., 2007. Tectono-sedimentary setting of the Oligocene-early 
Miocene deposits on the Betic-Rifian Internal Zone (Spain and Morocco). Geobios 40, $191-205$.

Sierro, F.J., Hilgen, F.J., Krijgsman, W., Flores, J.A., 2001. The Abad composite (SE Spain): a Messinian reference section for the Mediterranean and the APTS. Palaeogeography, Palaeoclimatology, Palaeoecology 168, 141-169.

Siesser, W, de Kaenel, E., 1999. Neogene calcareous nannofossils: western Mediterranean biostratigraphy and paleoclimatology. In: R. Zahn, M.C. Comas, A. Klaus (Eds.), Leg 161, Proceedings of the Ocean Drilling Program, Scientific Results $161,223-237$.

Sissingh, W., 1972. Late Cenozoic ostracoda of the South Aegean island arc. Utrecht Micropaleontological Bulletin 6, 1-187.

Snel, E., Mărunţeanu, M., Macaleţ, Meulenkamp, J.E., van Vugt, N., 2006. Late Miocene to Early Pliocene chronostratigraphic framework for the Dacic Basin, Romania. Palaeogeography, Palaeoclimatology, Palaeoecology 238, 107-124.

Soria, J.M., Caracuel, J.E., Corbí, H., Dinarès-Turell, J., Lancis, C., Tent-Manclús, J.E., Yébenes, A., 2008. The Bajo Segura Basin (SE Spain) : implications for the Messinian salinity crisis in the Mediterranean margins. Stratigraphy 5, 257-263.

Soria, J.M., Caracuel, J.E., Corbí, H., Yébenes, A., 2007. La sedimentación de afinidad Lago Mare (Messiniense) y la transgresión del Plioceno en Alicante (Cuenca del Bajo Segura). Geogaceta 41, 219-222.

Spezzaferri, S., Cita, M.B., McKenzie, J., 1998. The Miocene/Pliocene boundary in the Eastern Mediterranean: results from Sites 967 and 969. In: Robertson, A.H.F., Emeis, 
K.-C. et al. (Eds.), Leg 160, Proceedings of the Ocean Drilling Program, Scientific Results 160, 9-28.

Sprovieri, M., Ribera d'Alcalà, M., Manta, D.S., Bellanca, A., Neri, R., Lirer, F., Taberner, C., Pueyo, J.J., Sammartino, S., 2008. Ba/Ca evolution in water masses of the Mediterranean late Neogene. Paleoceanography 23, PA3205, doi:10.1029/2007PA001469, 17 pp.

Suc, J.-P., Clauzon, G., Bessedik, M., Leroy, S., Zheng, Z., Drivaliari, A., Roiron, P., Ambert, P., Martinell, J., Doménech, R., Matias, I., Julià, R., Anglada, R., 1992. Neogene and Lower Pleistocene in Southern France and Northeastern Spain. Mediterranean environments and climate. Cahiers de Micropaleontologie 7 (1-2), 165186.

Suc, J.-P., Do Couto, D., Melinte-Dobrinescu, M.C., Macaleţ, R., Quillévéré, F., Clauzon, G., Csato, I., Rubino, J.-L., Popescu, S.-M., 2011. The Messinian Salinity Crisis in the dacic basin (SW Romania) and early Zanclean Mediterranean - Paratethys high sealevel connection. Palaeogeography, Palaeoclimatology, Palaeoecology 310, 256-272.

Suc, J.-P., Drivaliari, A., 1991. Transport of bisaccate coniferous fossil pollen grains to coastal sediments. An exemple from the earliest Pliocene Orb ria (Languedoc, southern France). Review of Palaeobotany and Palynology 70, 247-253.

Syrides, G.E., 1995. Neogene mollusk faunas from Strymon basin, Macedonia, Greece. First results for biochronology and palaeoenvironment. Geobios special issue, 18, 381388.

Syrides, G.E., 1998. Paratethyan mollusc faunas from the Neogene of Macedonia and Thrace, Northern Greece. Romanian Journal of Stratigraphy 78, 171-180. 
Torres-Roldán, R.L., 1979. The tectonic subdivision of the Betic Zone (Betic Cordilleras, southern Spain); its significance and one possible geotectonic scenario for the westernmost Alpine Belt. American Journal of Science 279, 19-51.

Van Couvering, J.A., Castradori, D., Cita, M.B., Hilgen, F.J., Rio, D., 2000. The base of the Zanclean Stage and of the Pliocene Series. Episodes 23 (3), 179-187.

Van de Poel, H.M., 1991. Messinian straligraphy of the Nijar Basin (S.E. Spain) and the origin of its gypsum-ghost limestones. Geologie en Mijnbouw 70, 215-234.

Vismara Schilling, A., Stardner, H., Cita, M.B., Gaetani, M., 1976. Stratigraphic investigations on the late Neogene of Corfou (Greece) with special reference to the Miocene/Pliocene boundary and to its geodynamic significance. Memorie della Società Geologica Italiana 16, 279-317.

Young, J.R., 1998. Chapter 9: Neogene. In: Bown, P.R. (Ed.), Calcareous Nannofossils Biostratigraphy. British Micropaleontological Society Publications Series, Kluwer Academic Press, Dordrecht, pp. 225-265.

Zonneveld, K.A.F., Marre, F., Versteegh, G.J.M., Bogus, K., Bonnet, S., Bouimetarhan, I., Crouch, E., de Vernal, A., Elshanawany, R., Edwards, L., Esper, O., Forke, S., Grøsfjeld, K., Henry, M., Holzwarth, U., Kielt, J.-F., Kim, S.-Y., ladouceur, S., Ledu, D., Chen, L., Limoges, A., Londeix, L., Lu, S.-H., Mahmoud, M.S., Marino, G., Matsouka, K., Matthiessen, J., Mildenhal, D.C., Mudie, P., Neil, H.L., Pospelova, V., Qi, Y., Radi, T., Richerol, T., Rochon, A., Sangiorgi, F., Solignac, S., Turon, J.-L., Verleye, T., Wang, Y., Wang, Z., Young, M., 2013. Atlas of modern dinoflagellate cyst distribution based on 2405 data points. Review of Palaeobotany and Palynology, 191, 1197. 
Table 1: Calcareous nannofossils recorded in the Río Mendelín, El Túnel, Zorreras (Sorbas) and Gafares (Nijar) sections. Location of samples in Figure 4.

Table 2: Mediterranean localities with Paratethyan-type organisms corresponding to Lago Mare deposits located in Figure 12. 


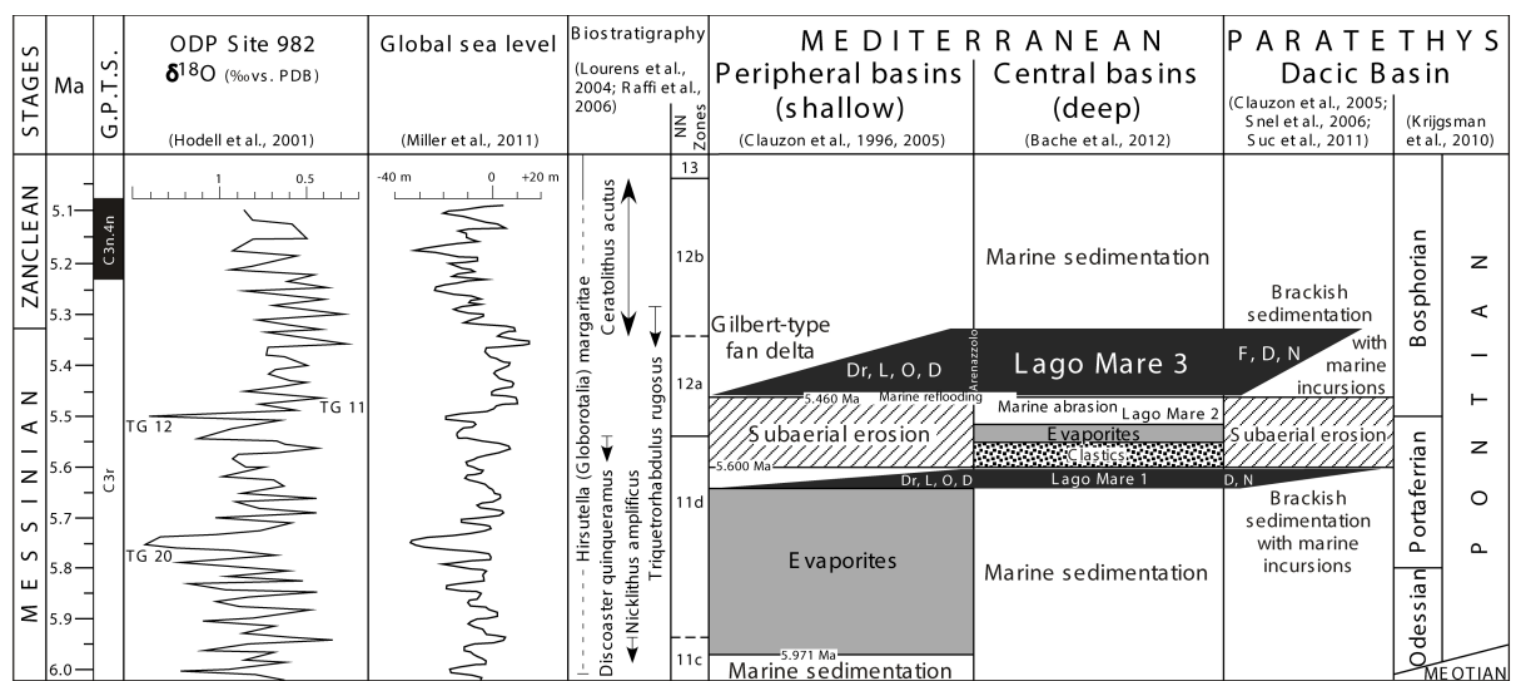

Fig. 1: Chronotratigraphy of the events related to the Messinian Salinity Crisis in the peripheral and central Mediterranean basins: deposition of evaporites, subaerial and marine erosion, Lago Mare (Bache et al., 2012). Correlations with the $\delta 180$ curve from Site 982 from the benthic foraminifer Cibicidoides kullenbergi (Hodell et al., 2001) on which has been established and adjusted the global sea level curve from Miller et al. (2011). Relationships with the Eastern Paratethys are indicated by double arrows (Clauzon et al., 2005; Popescu et al., 2009). Chronology is from Bache et al. (2012) and Manzi et al. (2013). Molluscs: Dr, Dreissenids; L, Lymnocardiids; O, Ostracods; D, Dinoflagellate cysts; F, Foraminifers; N, Calcareous nannofossils. 


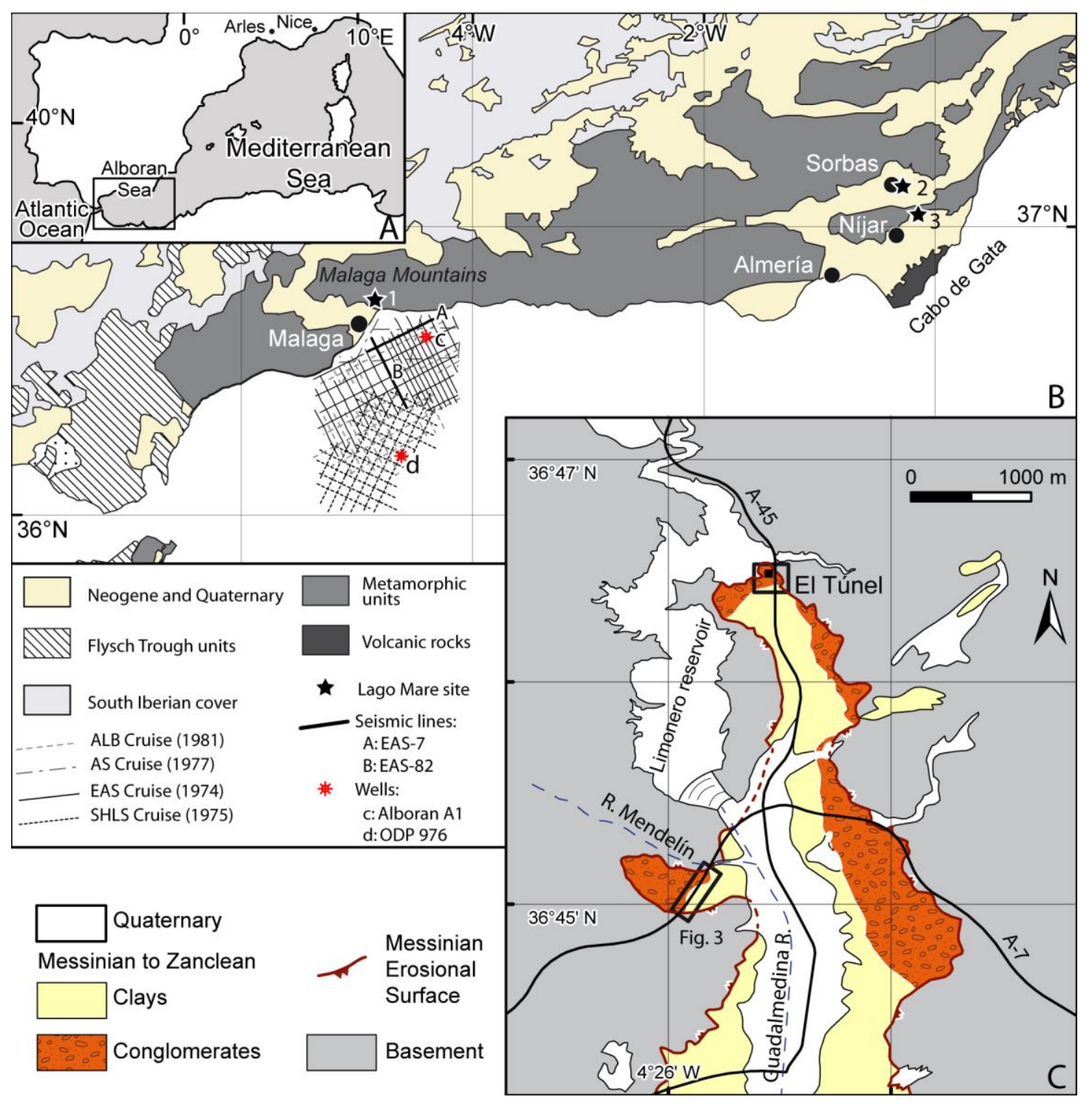

Fig. 2: General location maps.

A, Studied area; B, Onshore geological sketch of the northern Alboran Sea with the studied areas (1, Río Mendelín and El Túnel near Malaga; 2, Zorreras near Sorbas; 3, Gafares near Nijar). Thick lines point out the seismic profiles shown in Figures 9A and $9 B$ within the available seismic database used for the $3 D$ reconstruction in Figure $9 C ; C$, Location map and geological map of the area northward of Malaga.The geological map is from Estévez González and Chamón Cobos (1978). Boxes indicate the studied sections (Río Mendelín and El Túnel) with the corresponding figures. 


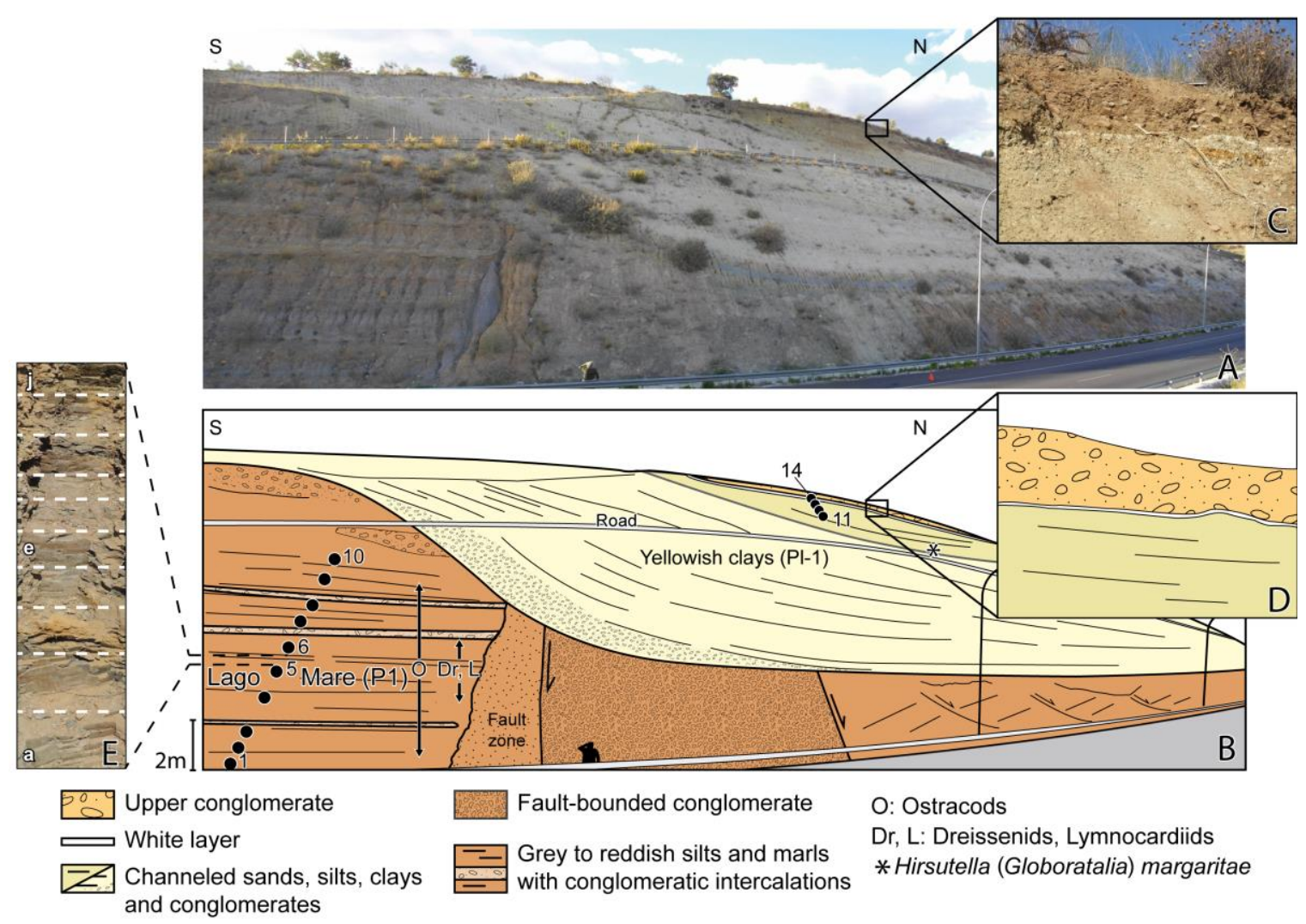

Fig. 3: The studied Río Mendelin section. A, Photograph of the sampled section; B, Log of the section with location of samples 1 to 14 (distance between two successive samples is indicated in Table 1); $C$, Photograph of the marine-continental transition; D, Log of the marine-continental transition; E, Zoomed photograph of the continuously sampled interval between samples 5 and 6 (samples $a-j$; distance between two successive samples: $10 \mathrm{~cm}$ ). 

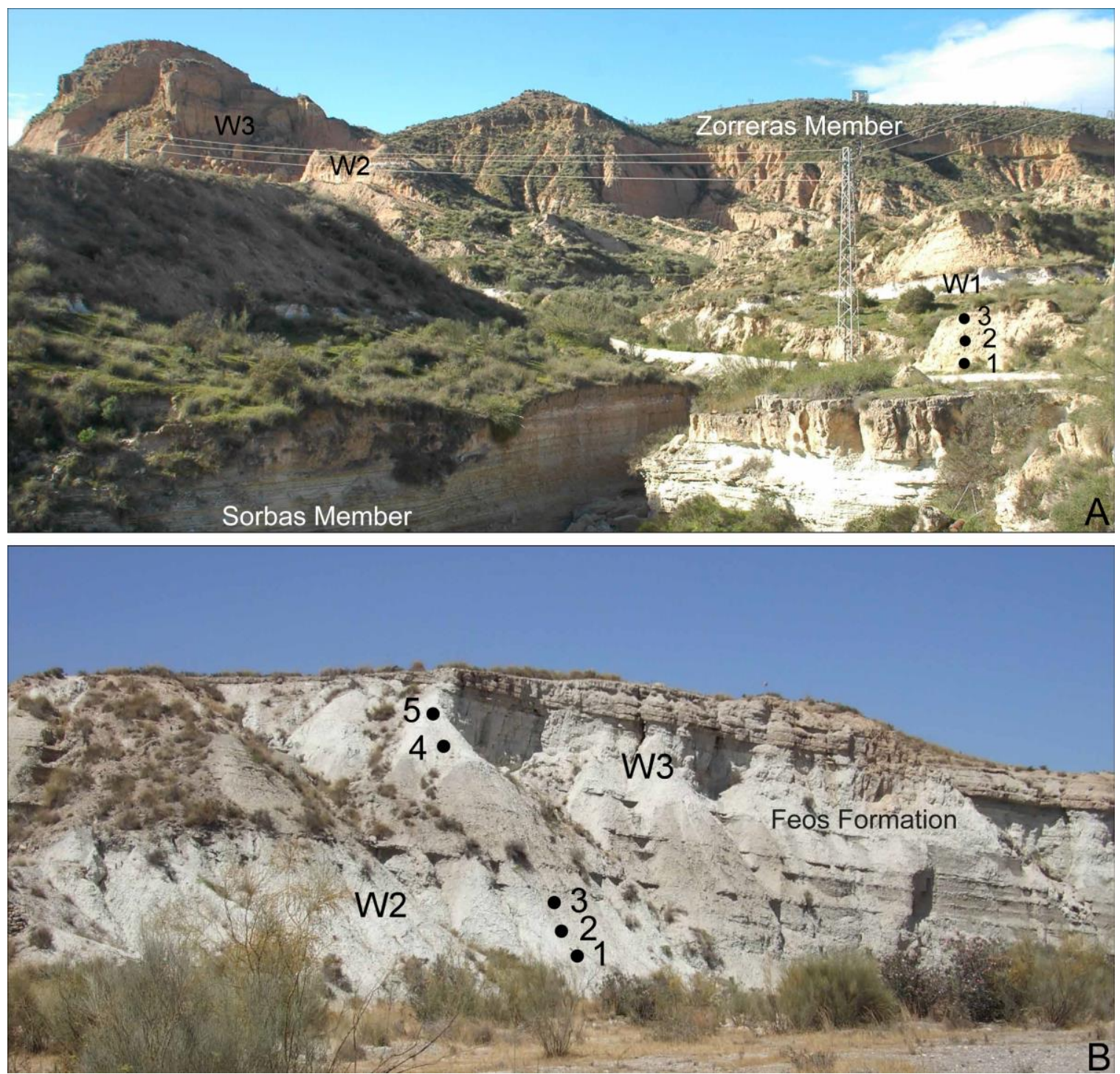

Fig. 4: Lago Mare deposits in the region of Almería. A, View of the Zorreras section, near Sorbas. B, View of the Gafares section, near Nijar. W1, W2, W3: whitish clayey layers; 1, 2, 03: location of the studied sample 

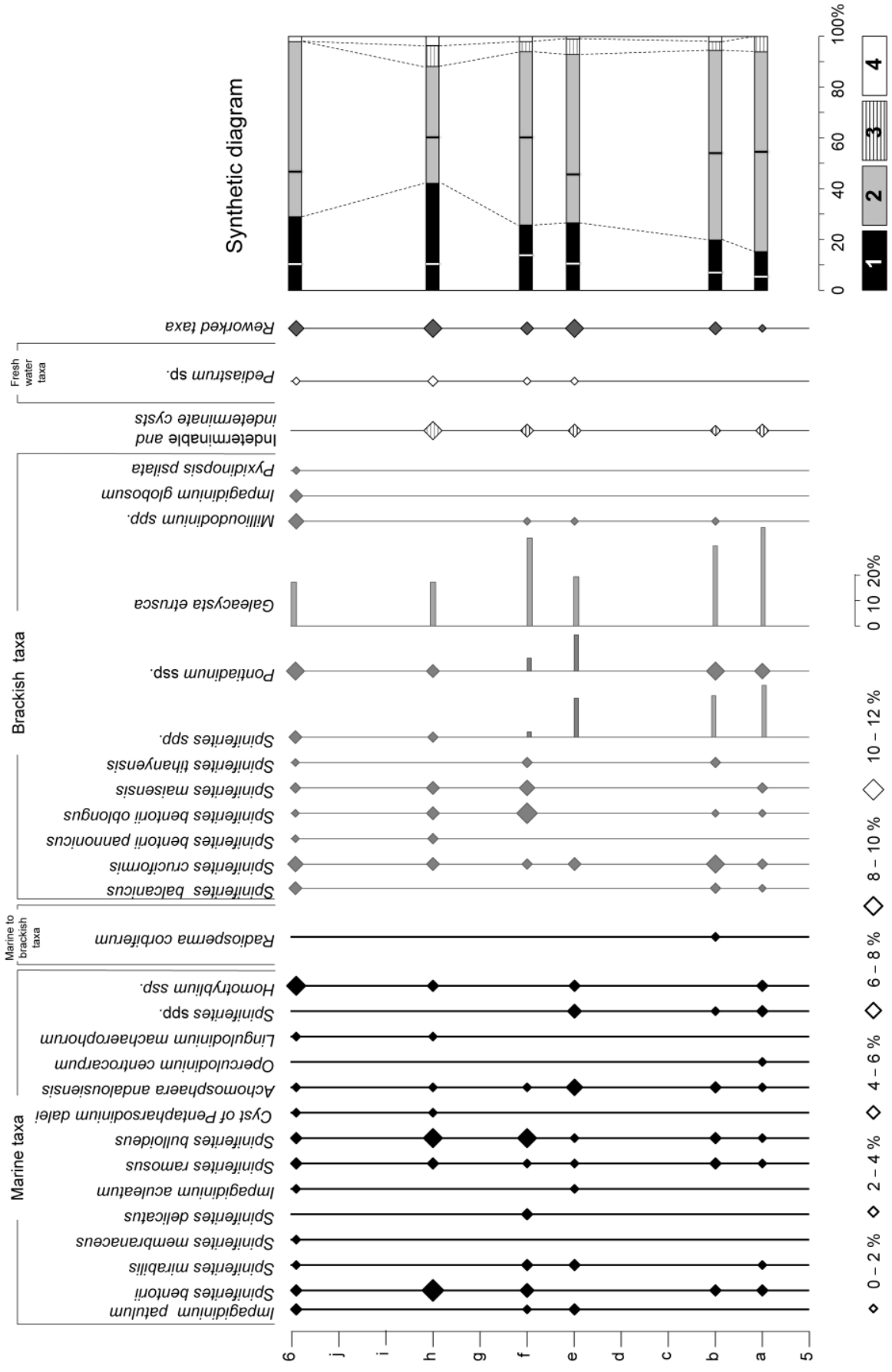

Fig. 5: Dinoflagellate cysts recorded in the Rio Mendelin section, grouped according to their ecological significance. Synthetic diagram shows the relative abundance of the groups: 1, marine taxa (white line separates stenohaline species to the left from euryhaline taxa to the right); 2, brackish taxa (black line separates Galeacysta etrusca to the left from the other taxa to the right); 3, indeterminable plus indeterminate cysts; 4 , freshwater taxa. Spiniferites spp. are indicated both as marine and brackish taxa. They are mostly made of fragments which prohibit a species ascribtion but can be ecologically classified according to their morphology. 

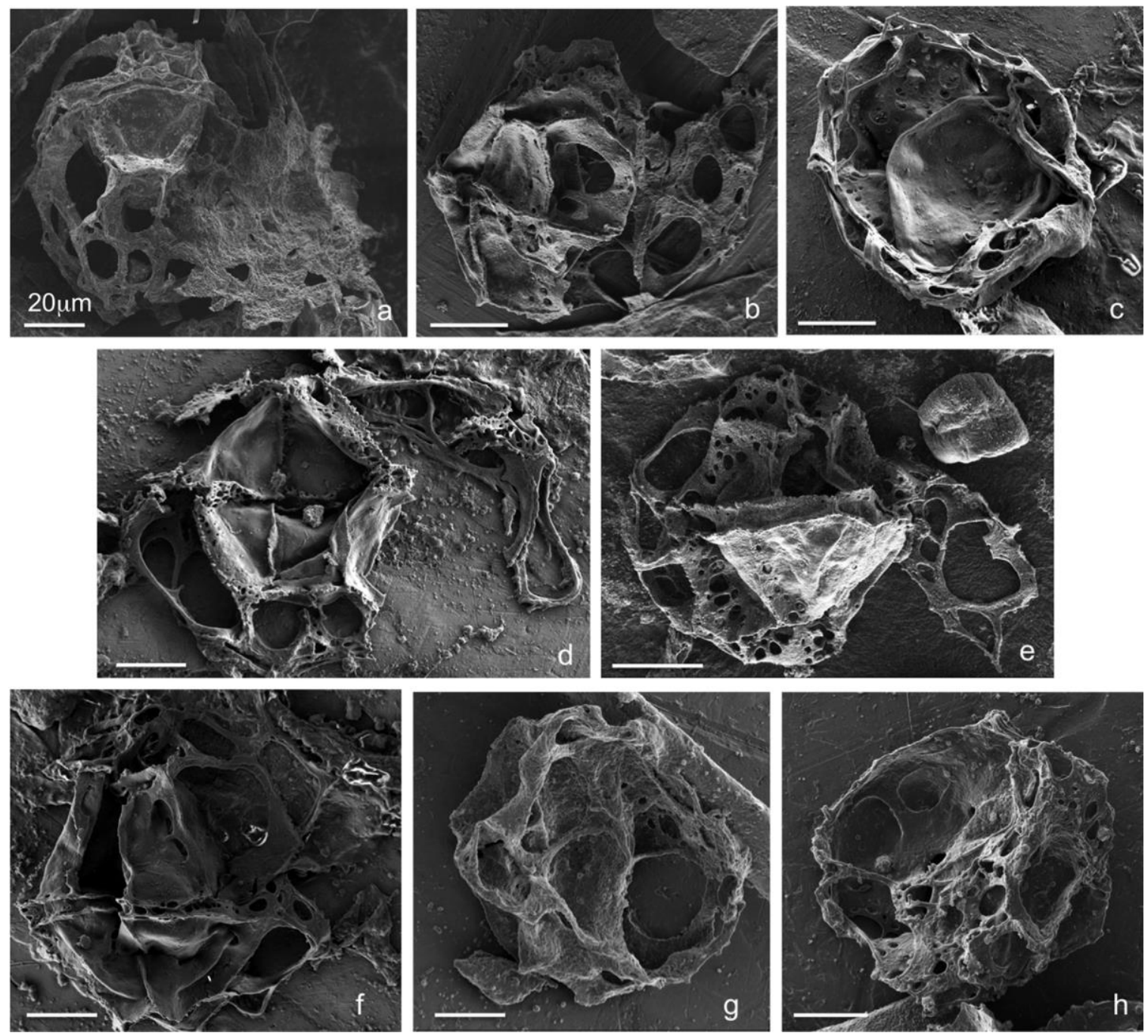

Fig. 6: Photographs of some specimens of Galeacysta etrusca recorded in the Lago Mare deposits of the Rio Mendelín section: views $c, d$ and $f$ are from sample $e$; views $g$ and $h$ are from sample f; views $a, b$ and e are from sample 6 . View $a$, note the occurrence of $a$ cyst of Pediastrum close to G. etrusca. Scale bar: $20 \mu \mathrm{m}$. 

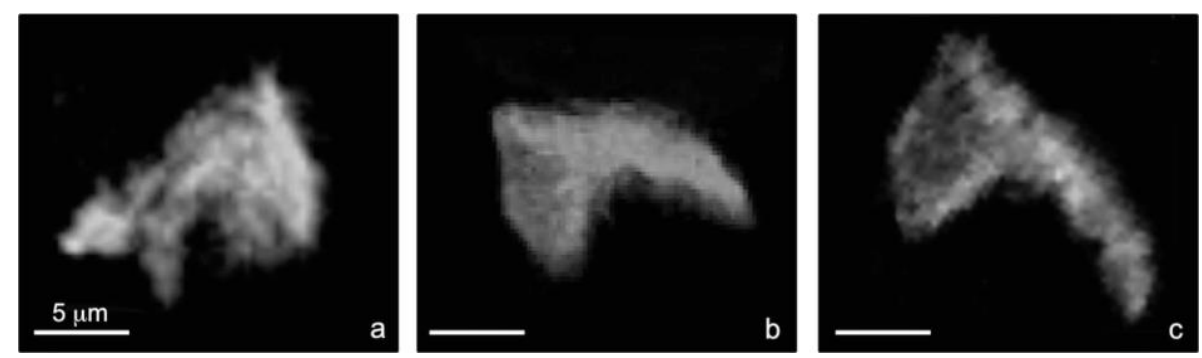

Fig. 7: Photographs of some specimens of Ceratolithus acutus (crossed Nichols) recorded in the Lago Mare deposits of the Río Mendelín section: $a$ and b, sample 5; c, sample 6. Scale bar: $5 \mu \mathrm{m}$.

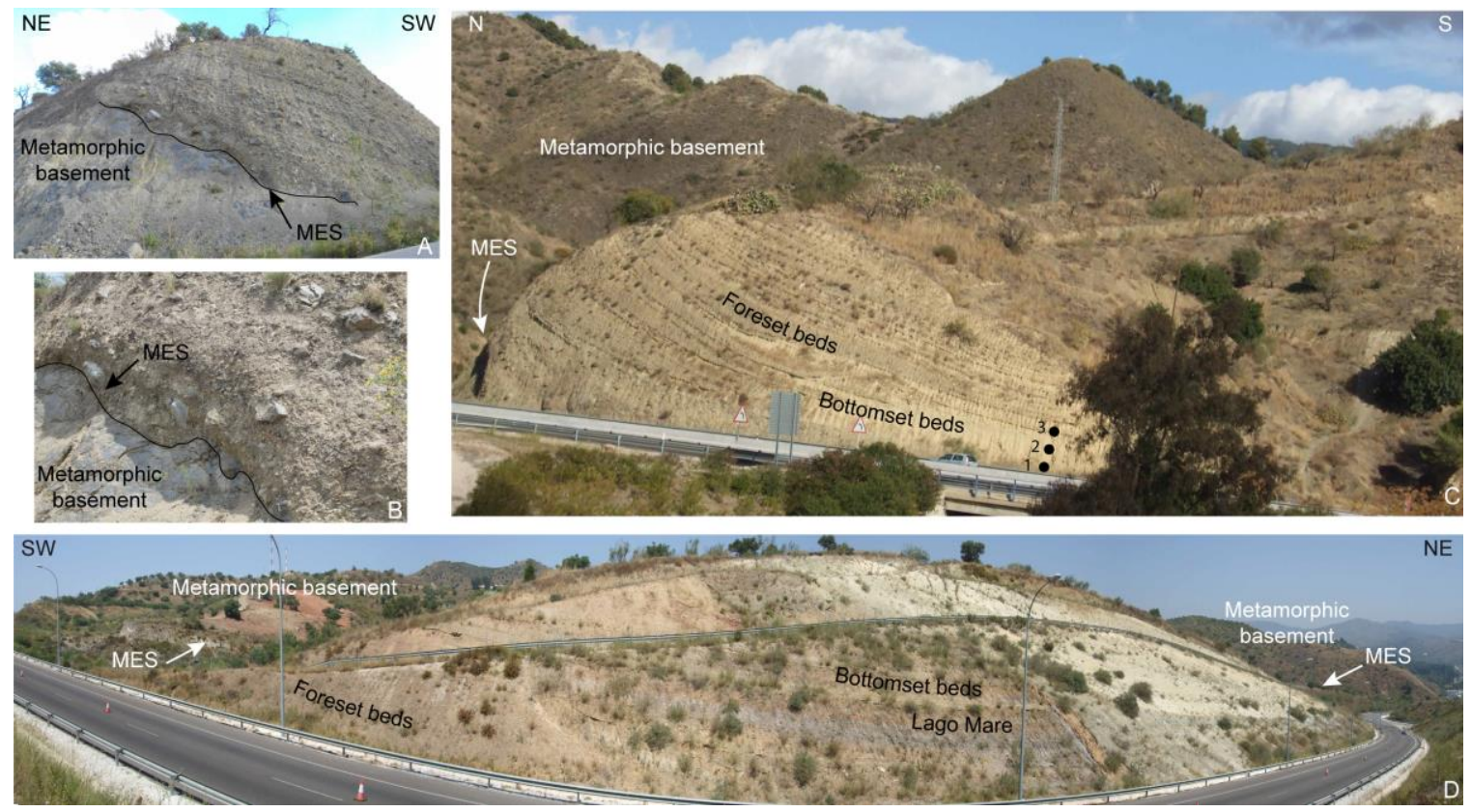

Fig. 8: The Gilbert-type fan delta of the Guadalmedina River (Malaga). A, Detailed view of the Messinian Erosional Surface separating the Gilbert-type fan delta deposits from the metamorphic basement. B, Photograph of a part of view $C$ at greater magnification. $C$, View of the proximal part of the Gilbert-type fan delta showing (1) the coarse blocks and the conglomeratic to sandy foreset beds overlying the Messinian Erosional Surface (MES) and the metaporphic basement, and (2) the sampled bottomset beds. D, Panoramic view of the Rio Mendelín section 

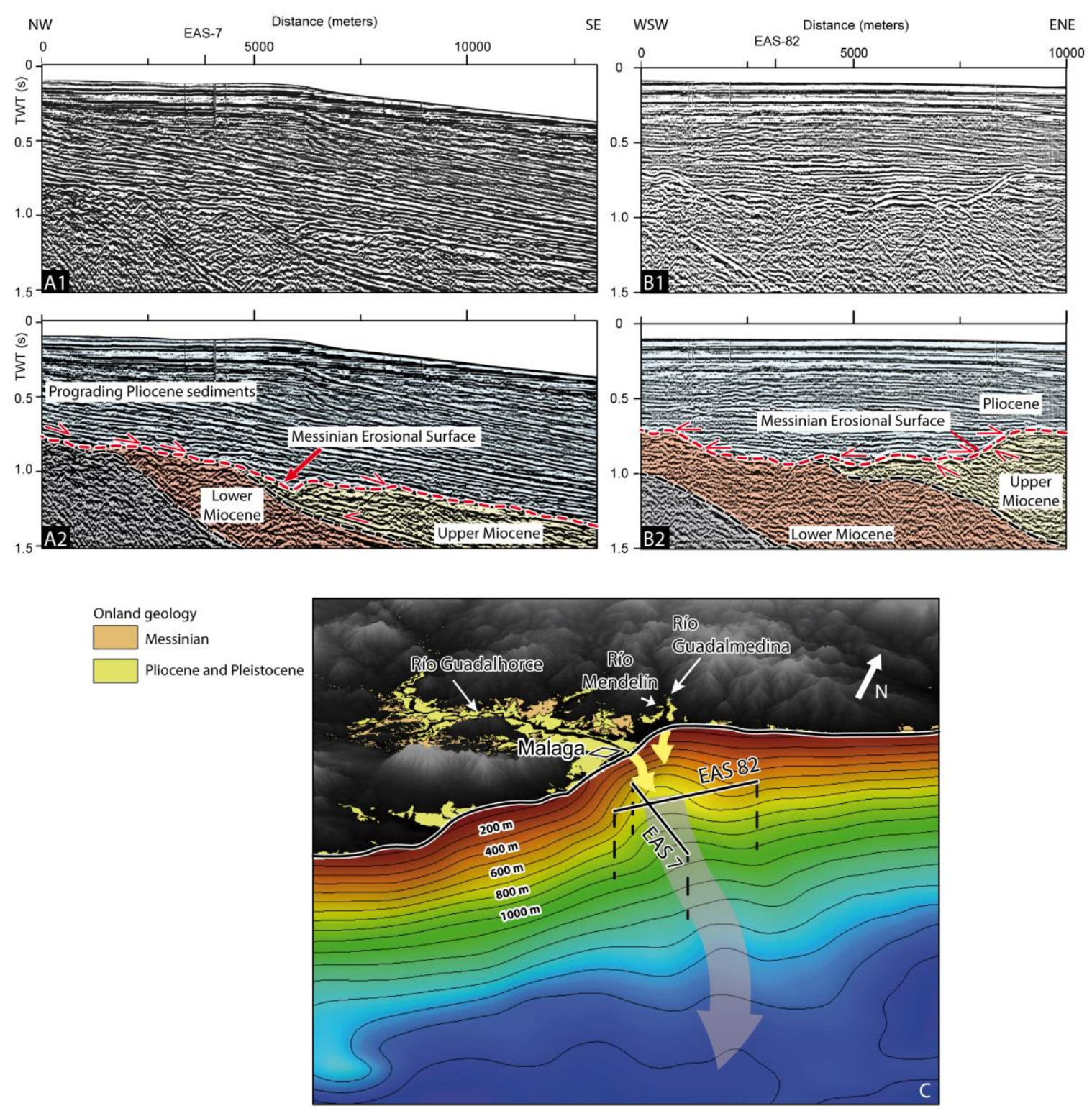

Fig. 9: Morphology of the Messinian Erosional Surface in the area of Malaga, from land to the Alboran Basin. Al and A2, Offshore non interpreted and interpreted seismic profile EAS-7, respectively; $B 1$ and B2, Offshore non interpreted and interpreted seismic profile EAS-82, respectively; $C$, Reconstructed paleo-bathymetry of the Messinian Erosional Surface, obtained from seismic data interpolation. 

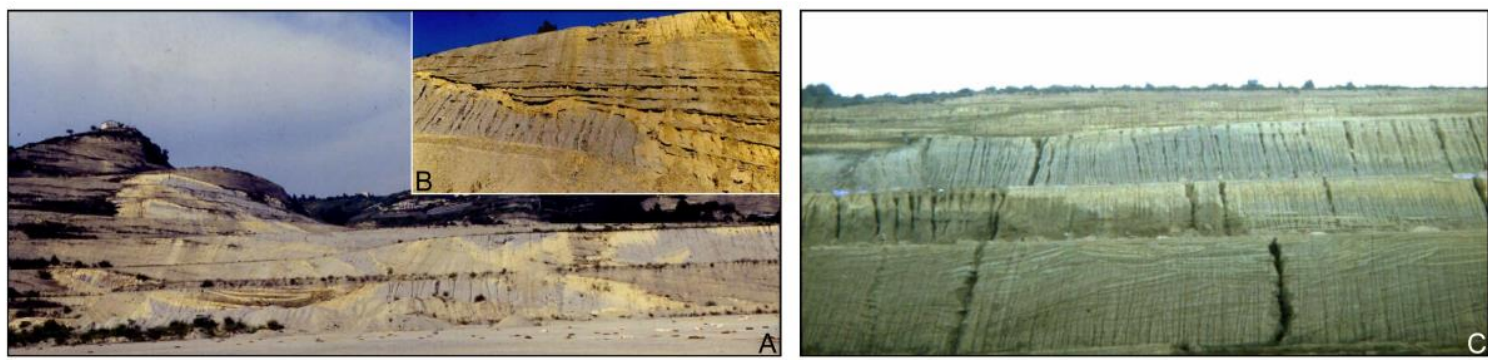

Fig. 10: Submarine erosional morphologies affecting bottomset and foreset beds of Zanclean Gilbert-type fan deltas in Southern France. A, General view of the Saint-Isidore quarry (Nice area); B, Saint-Isidore: detail of an erosional contact; $C$, General view of the Pichegu quarry (Arles area). 

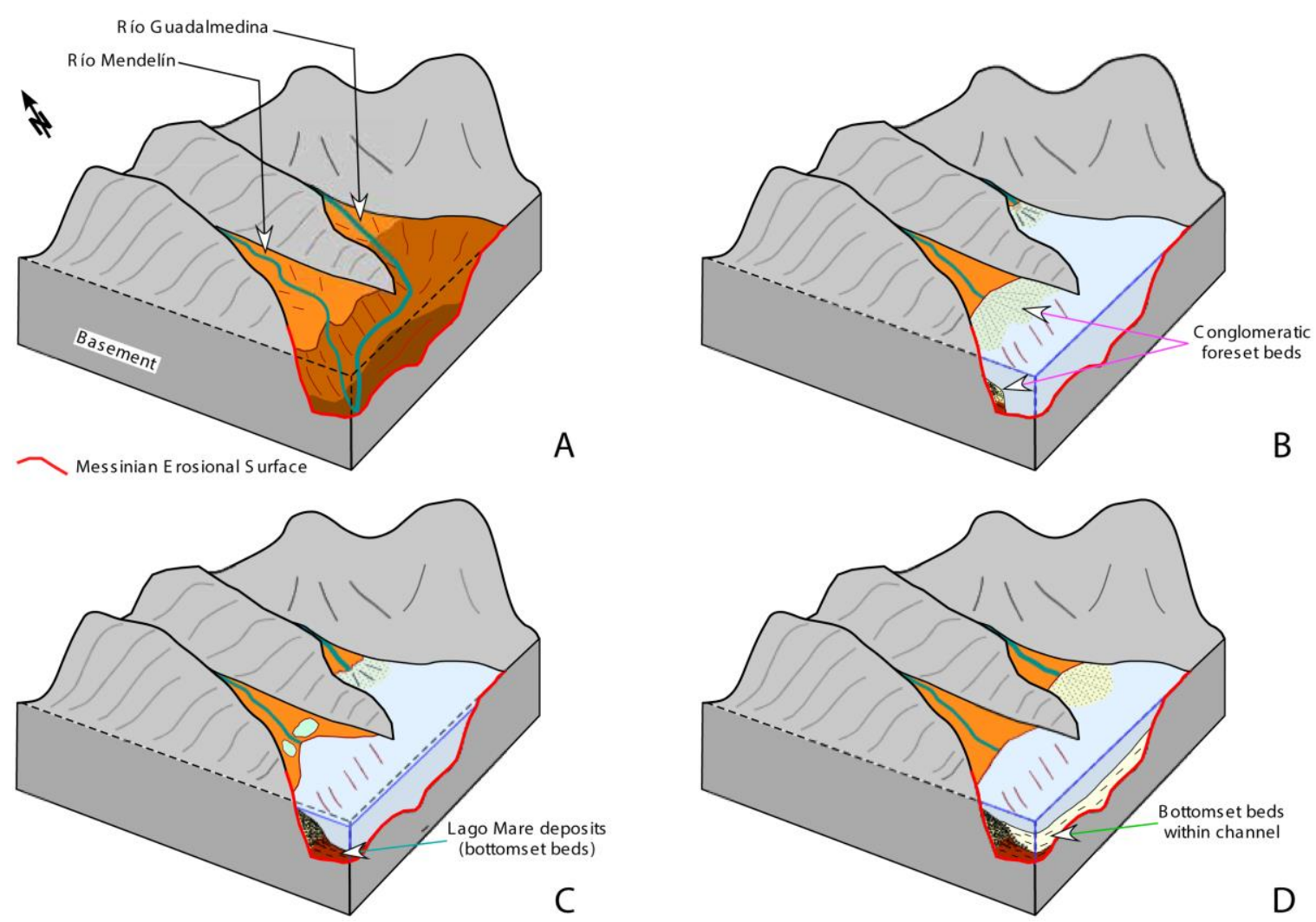

Fig. 11: Reconstructed paleogeographic and sedimentological evolution of the area northward of Malaga during and after the peak of the MSC (see Fig. 1 for the time schedule). A, At the time of the Mediterranean desiccation (5.600 Ma) when Rio Guadalmedina and Río Mendelín cut their valley; B, When the Mediterranean basin was reflooded by marine waters transforming the fluvial valleys into marine rias (5.460 Ma), allowing the onset of Gilbert-type fan delta progradation; $C$, During a slight sea-level fall at ca. 5.360 Ma leading a bay paleogeography in the Rio Mendelin ria with occurrence of some lagoons where molluscs of Paratethyan-type developed, the shells of which deposited in the bottomset beds; D, During the following sea-level rise (at ca. 5.350-5.332 Ma) resulting in increased development of Gilbert-type fan deltas and clayey bottomset beds affected by submarine erosion. 


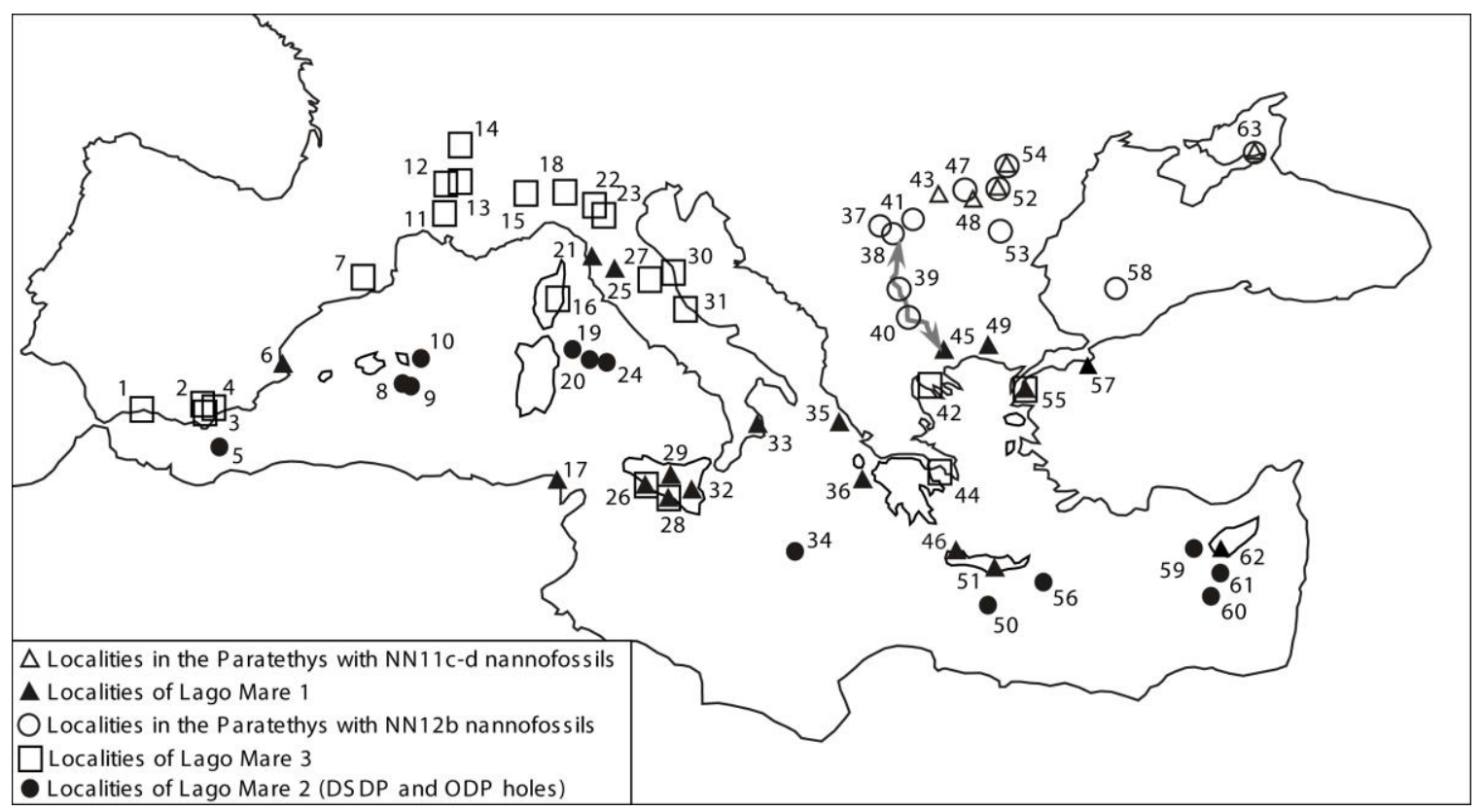

Fig. 12: Selected localities in the Mediterranean and Eastern Paratethys illustrating the three Lago Mare events. The probable gateway between the Aegean Sea and the Eastern Paratethys is indicated by a grey double arrow. Localities from West to East (references for the Mediterranean localities with Lago Mare biofacies are given in Table 2): 1, Rio Mendelín; 2, Zorreras; 3, Gafares; 4, Cuevas del Almanzora; 5, Site 978; 6, Monforte, Colmenar, Oami; 7, Papiol; 8, Site 124 ; 9, Site 975; 10, Site 372; 11, Théziers; 12, SaintMarcel d'Ardèche; 13, Saint-Restitut; 14, Allex; 15, Sioneri; 16, Casabianda; 17, Djebel Herageg; 18, Torre Sterpi; 19, Site 653; 20, Site 132; 21, Cava Serredi; 22, Monteglino; 23, Monticino; 24, Site 974; 25, Pomarance; 26, Eraclea Minoa; 27, Maccarone; 28, Capo Rossello; 29, Pasquasia; 30, Ancone; 31, Civitella del Tronto; 32, Vizzini; 33, Zinga; 34, Site 374; 35, Kavvadades; 36, Agios Sostis; 37, Turnu Severin; 38, Hinova; 39, Gabrovačka Reka; 40, Drăcevo; 41, Ticleni; 42, Trilophos; 43, Badislava; 44, Souvala; 45, Skini; 46, Khairetiana; 47, Doiceşti; 48, Bizdidel; 49, Mesi; 50, Site 969; 51, Faneromeni; 52, Călugăreni; 53, Argova Valley; 54, Valea Vacii; 55, Intepe; 56, Site 129; 57, Yalakdere; 58, Site 380; 59, Site 376; 60, Site 967; 61, Site 968; 62, Giolou; 63, Kerc. 


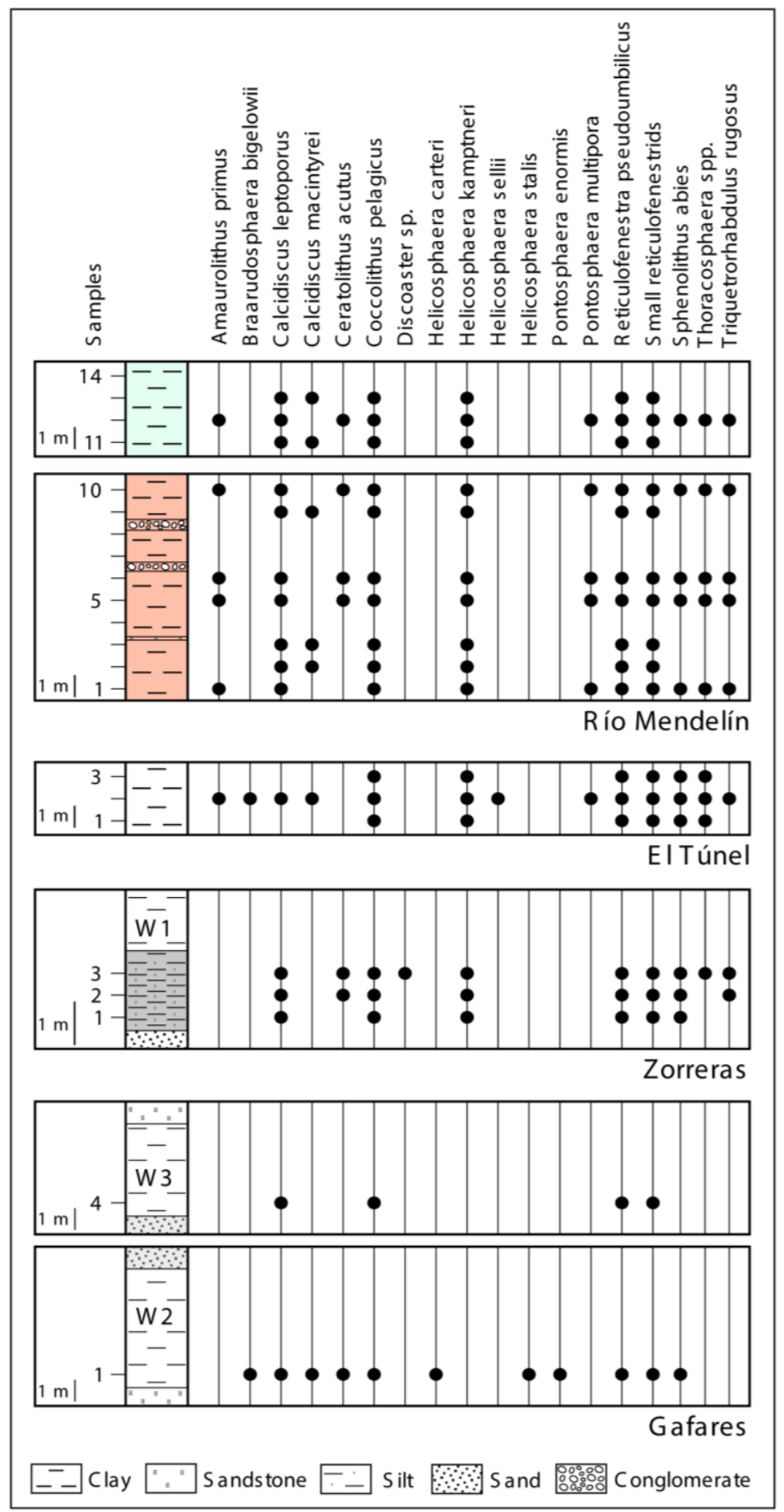

Table 1: Calcareous nannofossils recorded in the Río Mendelín, El Túnel, Zorreras (Sorbas) and Gafares (Nijar) sections. Location of samples in Figure 4. 


\begin{tabular}{|c|c|c|c|}
\hline Localities & $\begin{array}{c}\text { Dreissenids } \\
\text { Lymnocardiids }\end{array}$ & Ostracods & $\begin{array}{c}\text { Dinoflagellate } \\
\text { cysts }\end{array}$ \\
\hline $\begin{array}{l}\text { Alboran Sea: } \\
\text { (1) Río Mendelín* (Guerra-Merchán et al., 2010) } \\
\text { (2) Zorreras* (Civis et al., 1979; Roep and Van Harten, 1979) } \\
\text { (3) Gafares* (Roep and Van Harten, 1979; Bassetti et al., 2006) } \\
\text { (4) Cuevas del Almanzora (Cita et al., 1980) } \\
\text { (5) Site 978A (laccarino and Bossio, 1999) } \\
\text { (6) Monforte, Colmenar, Oami (Soria et al., 2007, 2008) }\end{array}$ & $\begin{array}{l}+ \\
+\end{array}$ & $\begin{array}{l}+ \\
+ \\
+ \\
+ \\
+ \\
+\end{array}$ & $+^{\star}$ \\
\hline $\begin{array}{l}\text { Northwestern Mediterranean: } \\
\text { (7) Papiol (Almera, 1894; Gillet, 1960, 1965) } \\
\text { (11) Théziers, (12) Saint-Marcel d'Ardèche , (13) Saint- } \\
\text { Restitut, (14) Allex (Fontannes, 1883; Ballesio, 1972; } \\
\text { Archambault-Guezou, 1976; Carbonnel, 1978) } \\
\text { (21) Cava Serredi (Bossio et al., 1981; Corradini and Biffi, 1988) } \\
\text { (25) Pomarance (Bossio et al., 1978) } \\
\text { (16) Casabianda (Pilot et al., 1975; Magné et al., } 1977 \text {; } \\
\text { Popescu et al., 2009) } \\
\text { (8) Site } 124 \text { (Benson, 1973) } \\
\text { (9) Site } 975 \text { (laccarino and Bossio, 1999) } \\
\text { (10) Site } 372 \text { (Benson, 1978; Cita et al., 1978) } \\
\text { (19) Site } 653 \text { (Cita et al., 1990) } \\
\text { (20) Site } 132 \text { (Benson, 1973) } \\
\text { (24) Site } 974 \text { (laccarino and Bossio, 1999) }\end{array}$ & $\begin{array}{l}+ \\
+ \\
+ \\
+ \\
+ \\
+\end{array}$ & $\begin{array}{l}+ \\
+ \\
+ \\
+ \\
+ \\
+ \\
+ \\
+ \\
+ \\
+\end{array}$ & + \\
\hline $\begin{array}{l}\text { Po Valley and Adriatic Sea: } \\
\text { (15) Sioneri (Cavallo and Repetto, 1988; Bertini, 2006) } \\
\text { (18) Torre Sterpi (Corselli and Grecchi, 1984; Popescu et al., } \\
\text { 2009) } \\
\text { (22) Monteglino (laccarino and Papani, 1979) } \\
\text { (23) Monticino (Marabini and Vai, 1988; Colalongo, 1988; Esu } \\
\text { and Taviani, 1989; Bertini, 1992) } \\
\text { (30) Ancone (Gillet, 1968) } \\
\text { (27) Maccarone (Carloni et al., 1974; Bertini, 1992; Popescu et } \\
\text { al., 2007, 2009) } \\
\text { (31) Civitella del Tronto (Pellen, 2011) }\end{array}$ & $\begin{array}{l}+ \\
+ \\
+ \\
+ \\
+\end{array}$ & $\begin{array}{l}+ \\
+ \\
+ \\
+ \\
+\end{array}$ & + \\
\hline $\begin{array}{l}\text { Central Mediterranean: } \\
\text { (17) Djebel Herageg (Burollet, 1952; Benson, 1976) } \\
\text { (28) Capo Rossello (Cita and Colombo, 1979; Bonaduce \& } \\
\text { Sgarrella, 1999) } \\
\text { (26) Eraclea Minoa (Decima \& Sprovieri, 1973; Bonaduce and } \\
\text { Sgarrella, 1999; Londeix et al., 2007; Popescu et al., 2009) } \\
\text { (29) Pasquasia (Colalongo, 1968; Cita et al., 1973) } \\
\text { (32) Vizzini (Di Geronimo et al., 1989) } \\
\text { (33) Zinga (Selli, 1973; Martina et al., 1979) }\end{array}$ & $\begin{array}{l}+ \\
+ \\
+\end{array}$ & $\begin{array}{l}+ \\
+ \\
+ \\
+ \\
+\end{array}$ & + \\
\hline $\begin{array}{l}\text { Ionian Sea: } \\
\text { (34) Site } 374 \text { (Cita et al., 1978) } \\
\text { (35) Kavvadades (Corfou) (Vismara Schilling et al., 1976) } \\
\text { (36) Agios Sostis (Zakynthos) (Kontopoulos et al., 1997) }\end{array}$ & & + & + \\
\hline $\begin{array}{l}\text { Aegean and Marmara seas: } \\
\text { (42) Trilophos (Gillet, 1937; Gillet and Geissert, 1971;Syrides, } \\
\text { 1998) } \\
\text { (44) Souvala (Aegina) (Rögl et al., 1991) } \\
\text { (45) Skini (Syrides, 1995, 1998) } \\
\text { (46) Khairetiana (Crete) (Sissingh, 1972) } \\
\text { (49) Mesi (Syrides, 1998) } \\
\text { (50) Site } 969 \text { (Spezzaferi et al., 1998) } \\
\text { (51) Faneromeni (Crete) (Cosentino et al., 2007) } \\
\text { (56) Intepe (Gillet et al., 1978; Melinte-Dobrinescu et al., 2009) } \\
\text { (56) Site } 129 \text { (Benson, 1973) } \\
\text { (57) Yalakdere (Gillet et al., 1978) }\end{array}$ & $\begin{array}{l}+ \\
+ \\
+ \\
+ \\
+ \\
+ \\
+\end{array}$ & $\begin{array}{l}+ \\
+ \\
+ \\
+ \\
+ \\
+\end{array}$ & + \\
\hline $\begin{array}{l}\text { Levantine Basin: } \\
\text { (59) Site } 376 \text { (Benson, 1978; Cita et al., 1978) } \\
\text { (60) Site } 967 \text { (Spezzaferi et al., 1998) } \\
\text { (61) Site } 968 \text { (Blanc-Valleron et al., 1998) } \\
\text { (62) Giolou (Cyprus) (Rouchy et al., 2001) }\end{array}$ & + & $\begin{array}{l}+ \\
+ \\
+ \\
+\end{array}$ & \\
\hline
\end{tabular}

Normal characters: Lago Mare 2 from deep basin localities Bold characters: localities ascribed to Lago Mare 3

Numbers in brackets refer to Figure 12

Table 2: Mediterranean localities with Paratethyan-type organisms corresponding to Lago Mare deposits located in Figure 12. 